\title{
New data from the Middle Palaeolithic Cotencher cave (Swiss Jura): site formation, environment, and chronology
}

\author{
Judit Deák $^{1}$, Frank Preusser ${ }^{2}$, Marie-Isabelle Cattin ${ }^{1}$, Jean-Christophe Castel ${ }^{3}$, and François-Xavier Chauvière ${ }^{1}$ \\ ${ }^{1}$ Office du patrimoine et d'archéologie Neuchâtel (OPAN), section Archéologie, Hauterive, Switzerland \\ ${ }^{2}$ Institute of Earth and Environmental Sciences, University of Freiburg, Freiburg, Germany \\ ${ }^{3}$ Muséum d'histoire naturelle Genève, Département d'archéozoologie, Genève, Switzerland
}

Correspondence: Judit Deák (judit.deak@ne.ch)

Relevant dates: $\quad$ Received: 17 September 2018 - Revised: 6 December 2018 - Accepted: 10 December 2018 Published: 10 January 2019

How to cite:

Deák, J., Preusser, F., Cattin, M.-I., Castel, J.-C., and Chauvière, F.-X.: New data from the Middle Palaeolithic Cotencher cave (Swiss Jura): site formation, environment, and chronology, E\&G Quaternary Sci. J., 67, 41-72, https://doi.org/10.5194/egqsj-67-41-2019, 2019.

Abstract:

Cotencher cave is one of the oldest Palaeolithic sites of Switzerland and is known for its rich faunal and Mousterian artefacts, the latter suggesting one or several passages of Neanderthal hunter-gatherer tribes. This interdisciplinary study summarises novel data concerning site formation processes and anthropic attendance of the site. While the lithic artefacts indicate tool production at the site, the faunal remains do not yield any evidence of a link to human occupation. The sedimentary sequence permits us to unravel several important environmental changes that occurred during the Late Pleistocene. The presence of a local glacier around $70 \mathrm{ka}$ (Marine Isotope Stage, MIS 4) is revealed followed by ice-free conditions characterised by alternating soil formation processes and landscape destabilisation during MIS 3. Solifluction processes suggesting recurrent frozen ground were responsible for the displacements of part of the artefacts and faunal remains. Evidence of local glacier development around $36 \mathrm{ka}$ is related to the particular geomorphological conditions of the studied region and shed new light on the complexity of glacier dynamics. The recognition and dating of recurrent hostile glacier landscapes might contribute to understanding the reasons for the Middle and Upper Palaeolithic attendance hiatuses known in the studied region.

Kurzfassung: Die Cotencher-Höhle ist eine der ältesten paläolithischen Fundstätten der Schweiz und bekannt für ihre reiche Fauna und mousterischen Artefakte. Letztere weisen darauf hin, dass NeanderthalerSippen aus Jägern und Sammlern die Region einmal oder mehrere Male durchstreift haben könnten. Diese interdisziplinäre Studie fasst neue Daten zu Standortbildungsprozessen und zu Aufenthalten von Menschen zusammen. Während die Steinartefakte eine Werkzeugproduktion an der Fundstelle anzeigen, geben die Faunenreste keine Hinweise auf eine Anwesenheit von Menschen. Die Sedimentabfolge erlaubt es, einige wichtige Umweltveränderungen während des späten Pleistozäns zu entschlüsseln. Die Präszenz eines lokalen Gletschers vor etwa 70 ka (Marines Isotopen Stadium, MIS 4) ist erkennbar, gefolgt von eisfreien Bedingungen, die durch sich abwechselnde Bodenbildungsprozesse und Landschaftsdestabilisierung während des MIS 3 charakterisiert sind. Solifluktionsprozesse, die auf wiederkehrend gefrorene Böden schließen lassen, waren verantwortlich für die Verlagerung eines Teils der Artefakte und Faunenreste. Die Bildung eines Lokalgletschers vor etwa 36 ka 
ist bedingt durch die speziellen geomorphologischen Gegebenheiten der untersuchten Region und geben neue Befunde über die Komplexität der Gletscherdynamik. Die Identifikation wiederkehrender lebensfeindlicher glazialer Landschaften könnte einen Beitrag dazu leisten, die phasenweise Abwesenheit von Menschen im Untersuchungsgebiet während des Mittel- und Oberpaläolithikums zu erklären.

\section{Introduction}

While Alpine glaciers extended several times onto the Swiss Plateau during the Pleistocene (Ivy-Ochs et al., 2008; Preusser et al., 2011), the Jura Mountains were also recurrently covered by local and sometimes Alpine ice bodies (Campy, 1992; Graf et al., 2007; Buoncristiani and Campy, 2011). During the Last Glacial Maximum (LGM), the ice cover reached up to $1200 \mathrm{~m}$ in the western part of the Swiss Plateau (Campy, 1992; Bini et al., 2009; Cupillard et al., 2015) and most sediments and soils previously covering the landscape as well as their archaeological content were removed by glacial erosion. As a consequence, Lower and Middle Palaeolithic sites are scarce in the region and the Middle Palaeolithic is documented at only about 20 open air, rock shelter, and cave sites (Le Tensorer, 1993, 1998; Tillet, 2001; Crotti, 2008; Detrey, 2010, 2013). Among these, Cotencher cave is the first Middle Palaeolithic site ever discovered in the Jura Mountains of Switzerland (Egloff, 1989).

Only a few records of Pleistocene environmental change are available from the Swiss Alpine foreland and in the Jura Mountains for the time before the LGM (Ivy-Ochs et al., 2008; Preusser et al., 2011; Heiri et al., 2014; Cupillard et al., 2015). Cave and rock shelter deposits have the potential to provide valuable additional information in this context due to their relatively protected setting compared to potentially more easily eroding open-air sites. These landscape elements were also places of human activity, and geoarchaeological studies aim at understanding the processes behind site formation (Goldberg and Macphail, 2006). Cave deposits are subdivided into clastic and chemical sediments (Goldberg and Macphail, 2006; White, 2007). The clastic sediments originate from either inside (autochthonous) or outside (allochthonous) of the cave and comprise weathering detritus, rock breakdown, entrance talus, infiltrates, and fluvial, glacial, and aeolian deposits. In addition, biogenic debris and anthropogenic layers may occur. Chemical deposits are considered to be in situ formed (autochthonous) and include speleothems, evaporates, ice, and phosphate and nitrate minerals originating from guano and bone alteration. Thus, caves and rock shelters are locations of numerous simultaneous or superposed depositional processes. Understanding these processes and their environmental causes is particularly challenging and often performed within interdisciplinary investigations (e.g. Goldberg et al., 2003; Angelucci et al., 2013; Boschian et al., 2017).
The most common approach to determine the age of cave deposits is radiocarbon dating of organic remains, in particular charcoal and bones, incorporated into sediments (Hajdas, 2008; Taylor and Bar-Yosef, 2014). Usually, this method is considered reliable despite potential problems related to reworking that may lead to radiocarbon ages older than the time of sediment deposition (e.g. Lee et al., 2011). Furthermore, radiocarbon ages $\geq 30000{ }^{14} \mathrm{C}$ yr tend to underestimate the real age, and ages beyond $50000{ }^{14} \mathrm{C}$ yr are generally not considered reliable (e.g. Hajdas et al., 2007; Higham, 2015). Other approaches include the dating of speleothem formation with the U-series methodology, in particular when applied to flow stones (St Pierre et al., 2009). An important improvement was the introduction of luminescence dating to date cave deposits (Feathers, 1996; Roberts, 1997; Roberts et al., 2015). Using optical stimulation, this approach allows us to directly date the deposition age of quartz and feldspar grains from sediments found in caves. However, the method is also affected by several potential problems that need careful consideration (Jacobs and Roberts, 2008). First, the luminescence signal might not have been fully reset prior to deposition (partial bleaching), which will lead to overestimation of ages. As grains have individual light exposure histories, measuring very few or even individual grains allows the detection of and correction for this effect using statistical approaches (e.g. Duller, 2008). Indication for partial bleaching is a wide-spread and positively skewed distribution, in combination with high overdispersion values (e.g. Rittenour, 2008). Second, while quartz is mainly the preferred mineral in luminescence dating, quartz from certain regions including the Alps is problematic with regard to its signal properties (e.g. Preusser et al., 2006). At the same time the luminescence signal in feldspar can be affected by unstable signal components that may lead to age underestimation. While the signal loss can be monitored in the laboratory and approaches have been suggested to correct for it (Huntley and Lamothe, 2001), these procedures have been shown to often be problematic (e.g. Wallinga et al., 2007; Lowick et al., 2012). An alternative might be to use more stable signal components from feldspar (Thomsen et al., 2008), but at the cost of a slower resetting by daylight (Buylaert et al., 2012), which might be problematic in settings with short-distance transport. Third, reconstructing annual dose rate can be complex in cave settings (e.g. Guérin et al., 2017) and radioactive disequilibrium in the uranium decay chain may occur (e.g. Olley et al., 1997). 
Sediments of Cotencher cave have delivered rich faunal assemblages and more than 400 artefacts that were found in two distinct stratigraphical units. Already Dubois and Stehlin (1932/1933) discussed the relationship between the sedimentary sequence and past glaciations. More recent geoarchaeological studies define and characterise several stratigraphic units positioned between the Eemian and the Holocene (Adatte et al., 1991; Rentzel, 1990). The dating of the sequence is based on techno-typological elements, variation in the mineralogy, and a few charcoal radiocarbon ages. The latter, originating from two individual archaeological find layers, are at the upper dating limit and suggest a minimum age of $40 \mathrm{ka}$ for the lower part of the site. The youngest find layer was interpreted as being deposited during the Late Pleistocene (Marine Isotope Stage - MIS 3, cited as Interpleniglacial in Adatte et al., 1991). Based on clay mineralogy, the oldest archaeological layer is interpreted as last interglacial soil redeposited during the early Late Pleistocene (Adatte et al., 1991). According to the most favoured hypothesis the lithic artefacts represent Mousterian Charentian of oriental Quina type originating from a single archaeological level situated originally at the entrance of the cave and redeposited during the two time intervals mentioned above (Bernard-Guelle, 2004).

As part of a regional landscape and natural resource coordination plan (Chauvière et al., 2018b, c; Deák, 2018a, b) two sections close to the entrance of the cavity were investigated. Establishing a more precise and detailed chronology of the sedimentary sequence was the main target, as the radiometric and archaeologic dating available so far were imprecise and incomplete. The present study focuses on the pre-Holocene sedimentary sequence hosting numerous Pleistocene faunal remains and Palaeolithic artefacts. We present the results of an interdisciplinary approach that provides not only a more detailed chronological framework but also completes our knowledge concerning the environmental changes recorded in the sediment fill. Furthermore, the archaeological finds are discussed in the larger context of Middle Palaeolithic occupations in Switzerland and neighbouring France.

\section{Research context}

\subsection{Regional setting}

Cotencher cave is located in the Areuse canyon, which is part of the Travers Valley (Canton Neuchâtel, Switzerland; Fig. 1). The entrance is at $660 \mathrm{~m}$ in altitude and situated $140 \mathrm{~m}$ above the present-day valley bottom. The cave is about $18 \mathrm{~m}$ long and consists of a $7 \mathrm{~m}$ long and $13 \mathrm{~m}$ wide rock shelter as well as an $11 \mathrm{~m}$ long underground gallery (Gigon, 1976; Fig. 2a and b). There is no evidence of recent or past karst springs or underground river activity. The cave is formed in Upper Jurassic limestones (Méia and Becker, 1976), more precisely at the interface between Kimmeridgian and Thitonian (Portlandian) strata (Dubois and Stehlin,
1932/1933). Late Quaternary undifferentiated glacial and glaciofluvial deposits interpreted as being of penultimate glacial (Rissian) age are present discontinuously on the neighbouring slopes (Méia and Becker, 1976); sediments attributed to the last interglacial and early phases of the last glacial cycle are apparently absent in the valley (Pasquier et al., 2013). Prior to previous archaeological excavations the cave was almost fully filled with sediment and one could enter it only by crawling (Gigon, 1976; Fig. 2b). Indeed, the maximum height of the internal gallery is about $5 \mathrm{~m}$ (Gigon, 1976, Miéville, 2005), where the sedimentary fill reached thicknesses of up to $4 \mathrm{~m}$.

\subsection{Research history}

Cotencher cave has been mentioned as early as $1523 \mathrm{CE}$ (Miéville, 2005), but the first excavations inside the cavity only date back to the second half of the 19th century (Otz, 1867; Desor, 1868, 1872). The latter permitted researchers to unravel the presence of old bones mainly attributed to cave bears (Ursus spelaeus). A high variety of faunal remains were confirmed by subsequent excavations that took place in 1915 and between 1916 and 1918 (Stehlin and Dubois, 1916; Dubois, 1917, 1918, 1920; Dubois and Stehlin, 1932/1933). The 1916-1918 excavations have a benchmark value and the results published in a monography (Dubois and Stehlin, 1932/1933) were the first to describe the complete stratigraphic sequence and defined (from youngest to oldest) the following stratigraphic units: (i) cryoclastic sediment (éboulis) containing Holocene archaeological remains (Dubois and Stehlin, 1932/1933; Vouga, 1943; De Rougemont, 1982); (ii) sterile white clay (argiles blanches); (iii) "gravelly layer" (couche à galets); (iv) "brown layer" (couche brune); and (v) a yellow basal clay (argile $d u$ fond). Detailed investigation of the sedimentary sequence and study of the various finds permitted scholars to recognise the changing environmental conditions recorded in the cave. Thousands of animal bones (belonging to about 60 species and sometimes burnt), dismantled fire places, and more than 400 lithic Mousterian artefacts attest to the presence of Neanderthal people during the time when the gravelly layer and the brown layer were formed (Dubois and Stehlin, 1932/1933; Egloff, 1976; Le Tensorer, 1998). This rich archaeological assemblage was further completed by illegal digs outside the cave in the 1950s. In 1964, a mandible fragment attributed to a ca. 40-year-old Neanderthal woman was discovered in the brown layer in the innermost part of the cave (Moll, 1971, 1974, 1977; Bay, 1981).

The first sedimentological analyses were performed in the 1950s (Schmid, 1958). Between 1988 and 1990, new excavations were accompanied by detailed sedimentological and mineralogical studies, permitting researchers to complete the understanding of the stratigraphic and environmental history (Fig. 3) (Rentzel, 1990, 1992; Adatte et al., 1991). According to these data the sedimentary record of the cave in- 


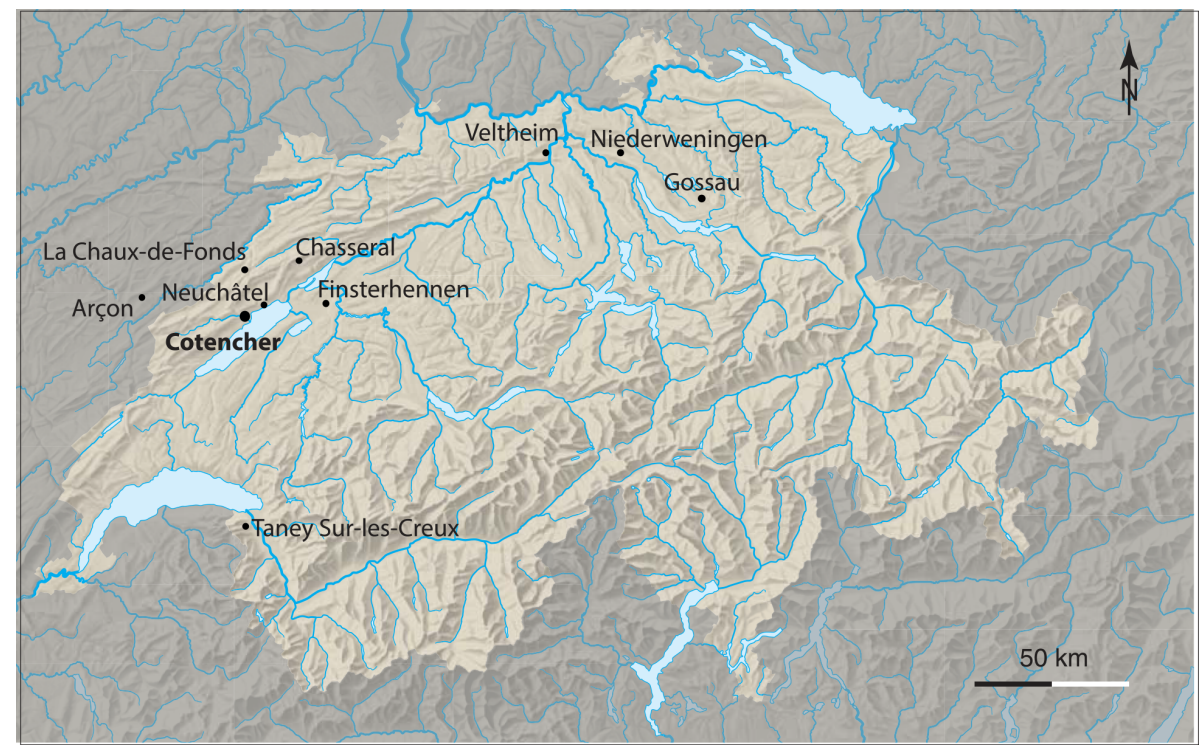

Figure 1. Location of Cotencher cave and of mentioned sites.

(a)

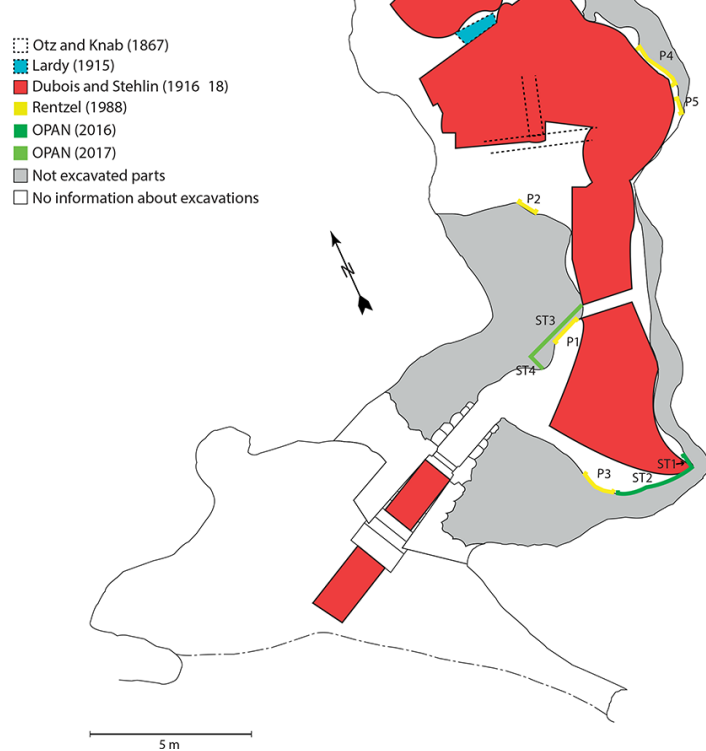

(b)

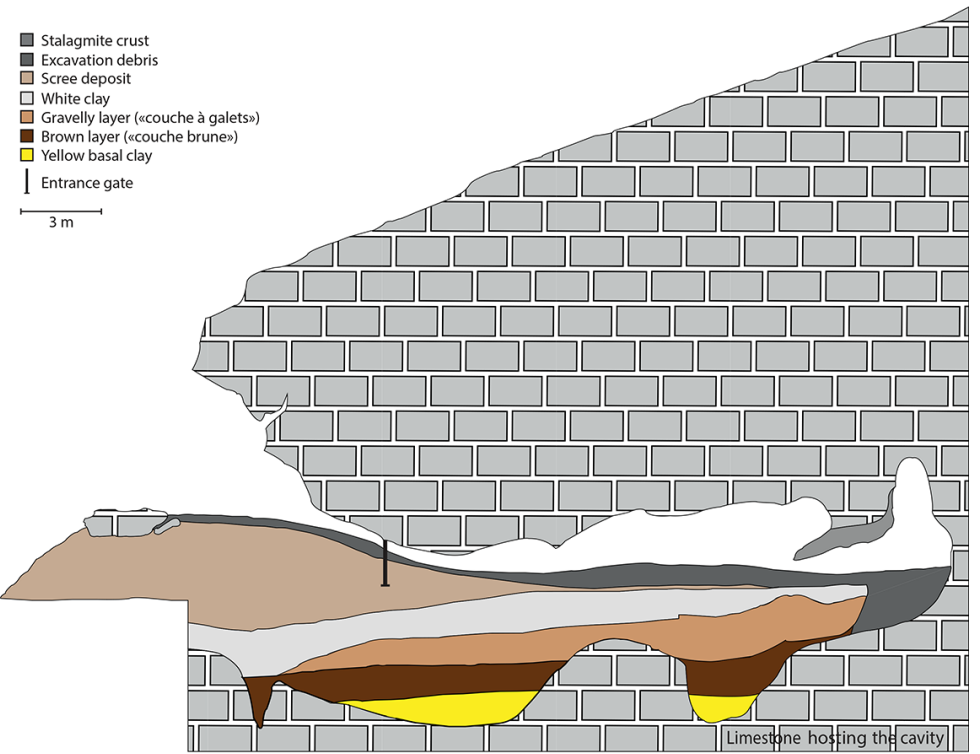

Figure 2. Map of the cavity with the localisation of the various interventions and sections mentioned in this paper (a) and longitudinal section of it based on Dubois and Stehlin (1932/1933) (b).

cludes (i) Holocene cryoclastic deposit (Layer I), (ii) two post-glacial finely textured layers (II and III), (iii) an Interpleniglacial gravelly layer (V), and (iv) sediment (brown layer or VI) interpreted as reworked Eemian soil. Three charcoal fragments found in the archaeological layers (two in the gravelly layer, one in the brown layer) gave radiocarbon ages of around $40000{ }^{14} \mathrm{C} \mathrm{yr} \mathrm{BP}$, considered minimum ages.
These results together with palaeontological and palynological data have been included in the synthetic work dedicated to the Palaeolithic in Switzerland by Le Tensorer (1998), who attributed the lowest archaeological find layer to the final part of the Odderade interstadial, while the gravelly layer was correlated with the Dürnten (Hengelo) phase. 
(a)

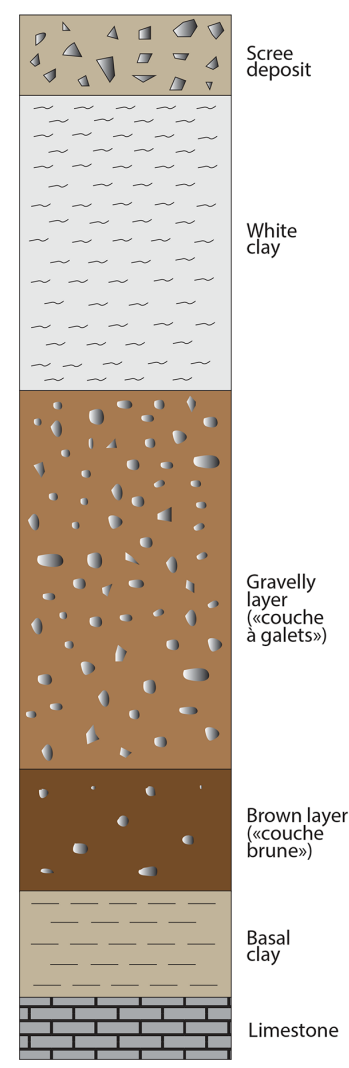

(b)

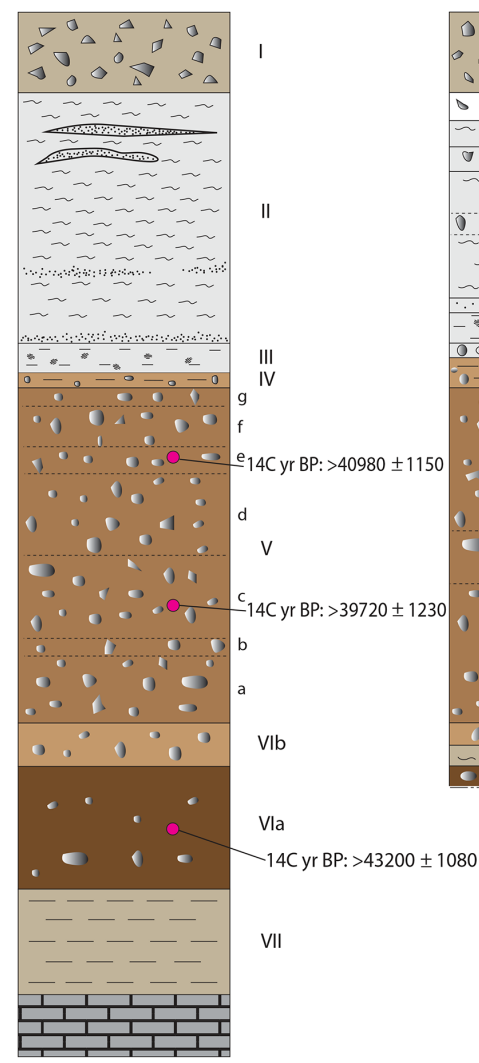

(c)

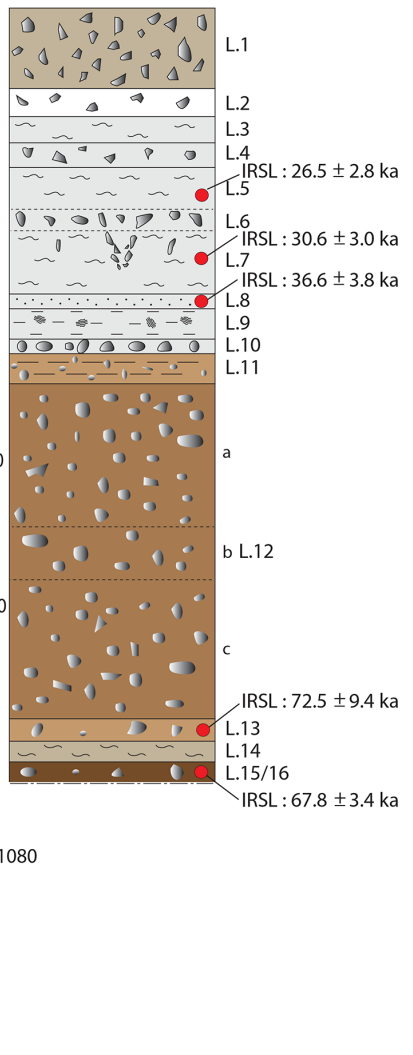

Figure 3. Synthetic overview of the stratigraphy of the site as recorded by the various studies. (a) Dubois and Stehlin excavations (Dubois and Stehlin, 1932/1933); (b) study by Renzel 1988 (Rentzel, 1990); (c) 2016 intervention presented in this paper and the dates obtained. Legend: on the right side of the columns the stratigraphic nomenclature used by the various authors is indicated.

\subsection{Climate and environment}

Present-day climate in the study region is characterised by mean annual temperatures of $9.4^{\circ} \mathrm{C}$ (Neuchâtel $485 \mathrm{~m}$ a.s.l.) and 6.3-6. $4^{\circ} \mathrm{C}$ (La Chaux-de-Fonds $1018 \mathrm{~m}$ a.s.l.; Chaumont $1136 \mathrm{~m}$ a.s.l.). For the same stations mean annual precipitations are 987, 1468 and $1289 \mathrm{~mm}$ (Météosuisse, 2016). The mean annual evaporation for the Neuchâtel station is $573 \mathrm{~mm}$ (Météosuisse, 2005); thus on an annual basis leaching conditions prevail.

Reconstruction of the Late Pleistocene terrestrial environmental history of the northern Alpine foreland and the Jura Mountains is based on discontinuously dated evidence from (i) lake pollen records, glacier melt-out and outwash deposits, and a few cave sites - all of them covered by the ice during the LGM, and (ii) some dolina deposits and loesspalaeosol sequences described in localities situated outside of the reach of LGM glaciers (Preusser et al., 2003, 2011; Preusser, 2004; Blant and Deriaz, 2007; Ivy-Ochs et al., 2008; Gaar and Preusser, 2012; Becker et al., 2013; Leesch et al., 2013; Heiri et al., 2014; Bichet et al., 2016). According to Preusser (2004), five rather cool to cold periods (stadials, S1-5) are delimited from warmer phases. The first marked cooling (S1/MIS 5d) after the last interglacial was possibly accompanied by a first glacier advance into the major alpine valleys, but its extension is not defined. It was followed by a period of rather warm conditions with boreal forest and some deciduous trees. This phase is usually correlated with the Brørup interstadial and MIS 5c. The geographical extension of the S2 glacier advance (MIS 5b) cannot be delimited due to subsequent erosion (Ivy-Ochs et al., 2008). The second interstadial of the Early Würmian (MIS 5a) was again characterised by boreal forest with some temperate taxa. For S3 (equivalent of MIS 4), glacial outwash deposits are documented relatively close to the studied site (Fig. 1), at Finsterhennen (Preusser et al., 2007) and at Arçon (Cupillard et al., 2015; Bichet et al., 2016). For the subsequent period (Middle Würmian, corresponding to MIS 3) a succession of more or less mild interstadials has been recognised at Gossau in the Lake Zürich area (Preusser et al., 2003). Its first phase, the Dürnten Interstadial of Welten (1981), featured open woodland vegetation with pine and spruce and likely dates to about $55 \mathrm{ka}$ (Wegmüller et al., 2002). Sites with faunal remains found both inside and outside the LGM limits indicate open tundra-steppe environment but temporarily with patches of 
boreal vegetation (Becker et al., 2013). The site of Niederweningen, dating to ca. $45 \mathrm{ka}$ (Hajdas et al., 2007; Preusser and Degering, 2007), has been particularly well investigated, with detailed reconstructions pointing towards open woodland conditions (Drescher-Schneider et al., 2007) and a rich fauna (Furrer et al., 2007). During the Late Würmian (MIS 2, LGM) all the alpine valleys and the surrounding lowlands were largely covered by ice (Ivy-Ochs et al., 2008) and the northern lobe of the Valais (Rhone) Glacier started to deposit proglacial sediments at Finsterhennen just after $30 \mathrm{ka}$ (Preusser et al., 2007). In the Jura Mountains local glaciers spread over substantial parts of the landscape (Campy, 1992; Buoncristiani and Campy, 2011). On its eastern flanks, during the most extensive phase of the LGM, local glaciers were subjugated by the Valais Glacier (Campy, 1992; Pasquier et al., 2013) and Cotencher cave was buried under about 500$600 \mathrm{~m}$ of ice (Campy, 1992).

\section{Methods}

\subsection{Excavation and documentation of archaeological finds}

Two almost perpendicular sections, situated close to the entrance of the cave ( 2.5 and $2 \mathrm{~m}$ high, respectively), have been cleaned for this study (Figs. 4 and 5). The sections have been divided into $50 \mathrm{~cm}$ large vertical bands and along each band the profiles were successively cleaned by horizontal segments. In the upper parts of the sections, the horizontal cleaning and sampling segments were $10 \mathrm{~cm}$, while in the lower parts, containing the archaeological find layers, the segments were $5 \mathrm{~cm}$ thick. All sediments originating from this cleaning process have been collected to be sieved and analysed. Samples for luminescence dating were taken by forcing metal tubes into the sediment exposure and additional material was taken for high-resolution gamma spectrometry. Undisturbed blocks were taken for thin section preparation and they are used here to estimate porosity. Detailed micromorphological studies are planned for a subsequent phase of this project.

All samples and the lithic and faunal finds discovered during the cleaning process were three-dimensionally positioned. The bulk samples were wet sieved (see below) and all bones and archaeological lithic fragments were carefully collected and documented. The sediments in the lower part of the studied sections are leftovers of former excavations or result from natural collapse of the cave walls. These have been $2 \mathrm{~mm}$ dry-sieved in front of the cavity and artefacts were collected. A detailed photographic documentation of the successive stages of field work was also performed (Fig. 4).

The entire collection of lithic artefacts (457), including the finds of the 2016 excavation, has been re-examined according to standard procedures. So far, only the bone assemblage of the 1916-1918 excavations has been assessed in detail with the purpose of verification of the identified bone fragments and their thorough examination, according the current standards with regard to the presence or absence of traces of human activity (Castel, 2010; Castel et al., 2017). The bone fragments found during the 2016 intervention will be analysed during a later phase of this project.

\subsection{Sedimentology and soil science}

Sedimentological and pedological observations were made on both sections to record the morphology, the nature and lateral variability in the soil, and the sediment characteristics. These observations were completed during infrastructure installation works in 2017. Although former studies (Dubois and Stehlin, 1932/1933, Rentzel, 1990) already proposed a nomenclature of the layers (Fig. 3), we observed a more detailed stratigraphy and renumbered layers starting from Layer 1 (L.1) at the upper part of the sequence. In order to assure the representativeness of derived data, samples had a weight between 1.1 and $15 \mathrm{~kg}$, the heavier samples being the gravelly layers. The bulk samples were air-dried, weighed, and subsampled for subsequent analyses. The remains were wet-sieved ( $8 \mathrm{~mm}, 4 \mathrm{~mm}, 2 \mathrm{~mm}$, and $500 \mu \mathrm{m}$ sieves) in order to recover archaeological material and to characterise the quantity and nature of the coarse fraction of the various layers. The material left on each sieve was air-dried and weighed. It is important to restate that for preservation issues sampling was restricted to a thin external part of the sections. As a consequence the granulometric values of the coarse fraction calculated here should be considered only as indicative. For detailed analyses of the fine fraction, we rely on Rentzel (1990). The organic carbon content was determined using the Walkley and Black method, while the $\mathrm{CaCO}_{3}$ content was measured with a calcimeter; both methods are explained in Mathieu and Pieltain (2003).

Petrographic and morphological investigation of the fraction $>8 \mathrm{~mm}$ of a set of selected samples, representative for each stratigraphic unit, was performed according to a protocol set up for this study. As the first screening revealed marked difference in size, petrography, and morphology of the pebbles from different layers, it was attempted to identify the stratigraphic origin of the calcareous rock fragments. As the available petrographic collections did not permit a clear stratigraphic attribution of the facies recognised, a sitespecific catalogue was established. Based on petrographic composition and morphology, different groups of gravel facies (GF1, GF2, etc.) were defined (Table 6). For all selected samples, weight, size, and morphology (roundness, surface roughness; Bullock et al., 1985) of the components of each group was recorded. Limestone banks enclosing the cavity on both the outside and inside were sampled as local limestone reference material (Ref. I, Ref. II., Table 6).

Based on the comparison with the reference material and morphological observations, five major coarse fraction groups have been defined (Table 6 and Fig. 9). Group A includes fresh rock fragments originating from the limestone layers hosting the cave. Group B includes rock fragments 

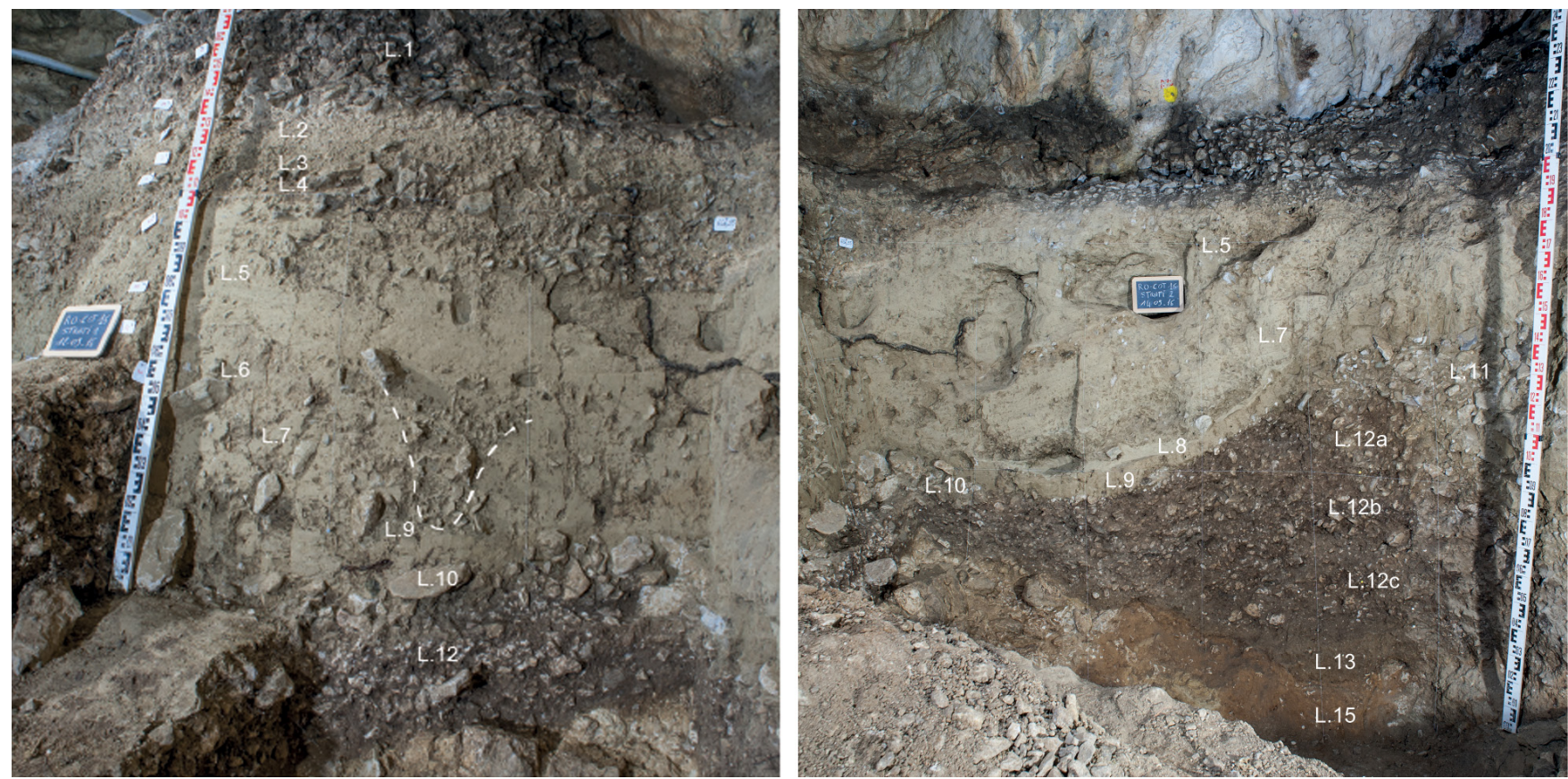

Figure 4. Field view of the observed and sampled sections. (a) Section 1 (ST1 location; see Fig. 2). Note the ice wedge cast at the contact between layers L.5 and L.7 and filled up with the gravels of L.6. (b) Section 2 (ST2 - location; see Fig. 2). Note the gully eroding the gravelly deposit L.12. (Photos: Marc Juillard, Laténium).

similar to limestone strata enclosing the cave but at least shortly transported. Group C includes rock fragments similar to the limestone strata enclosing the cave, but strongly rounded. Group D includes rock fragments not present in the strata enclosing the cave. Group E includes particular features. The rock fragments of groups A and B are considered to be autochthonous, originating from either the breakdown of limestone banks enclosing the cave or those forming the rock shelter. Rock fragments of groups $\mathrm{C}$ and $\mathrm{D}$ are clearly allochthonous as they either bear evidence of significant transport and/or their petrography is not present around the cave. The few rock fragments belonging to group E might be related with some human activity, but their quantity is too small to allow further interpretation.

\subsection{Luminescence dating}

Sample preparation for equivalent dose $\left(D_{\mathrm{e}}\right)$ determination was carried out in a red-light laboratory and included wetsieving $(100-150 \mu \mathrm{m})$ followed by removal of carbonates $(20 \% \mathrm{HCl})$ and organic matter $\left(30 \% \mathrm{H}_{2} \mathrm{O}_{2}\right)$. Clay particles were dispersed during combined $\mathrm{Na}$ oxalate and ultrasonic treatment. K feldspar and quartz fractions were separated using heavy liquids (Na polytungstate). The latter fraction was etched in $40 \% \mathrm{HF}$ for $1 \mathrm{~h}$, followed by $>1 \mathrm{~h} \mathrm{HCl}(10 \%)$ and re-sieving (to remove feldspar grains). Infrared (IR) screening revealed strong contamination of the quartz fraction with feldspar that could not be removed by further HF etching and all further work focused on $\mathrm{K}$ feldspar. It has to be noted that the amount of feldspar received during preparation was quite small due its low presence in the samples, and this limited the number of experiments and replicate measurements. Feldspar extracts were fixed on stainless steel discs using a $1 \mathrm{~mm}$ stamped spot of silicone oil, which will represent ca. 60 individual grains per disc.

Measurements for $D_{\mathrm{e}}$ determination were performed using a Freiberg Instruments Lexsyg Smart device (Richter et al., 2015), equipped with a Hamamatsu H7360-02 photomultiplier and using a combination of a Schott BG39 (3 mm) and a Brightline HC 414/46 interference $(3.5 \mathrm{~mm})$ filter. We applied the post-IR (pIR) infrared stimulated luminescence (IRSL) (Buylaert et al., 2009), with a preheat at $250{ }^{\circ} \mathrm{C}$ for $60 \mathrm{~s}$, a first IR stimulation at $50^{\circ} \mathrm{C}$ for $90 \mathrm{~s}$ (IR-50), and a subsequent second IR stimulation at $225^{\circ} \mathrm{C}$ for $100 \mathrm{~s}$ (pIR225), both with a power of $130 \mathrm{~mW} \mathrm{~cm}^{-2}$.

The performance of the protocol was monitored in dose recovery tests and we received recovery ratios of 0.90 for IR-50 and 1.12 for pIR-225, which are at the limits of the recommendations given by Wintle and Murray (2006) for such tests. To investigate potential residuals, six aliquots were exposed to the light of the inbuilt blue diodes subsequently three times for $30 \mathrm{~s}\left(100 \mathrm{~mW} \mathrm{~cm}^{-2}\right)$, followed by $D_{\mathrm{e}}$ determination using the pIR protocol. This shall exemplarily mimic repeated exposures of samples suspended in water (UV cut-off) to daylight. However, due to the complexity in nature with regard to light level, spectrum, and exposure times, this gives only a very rough idea of the dif- 

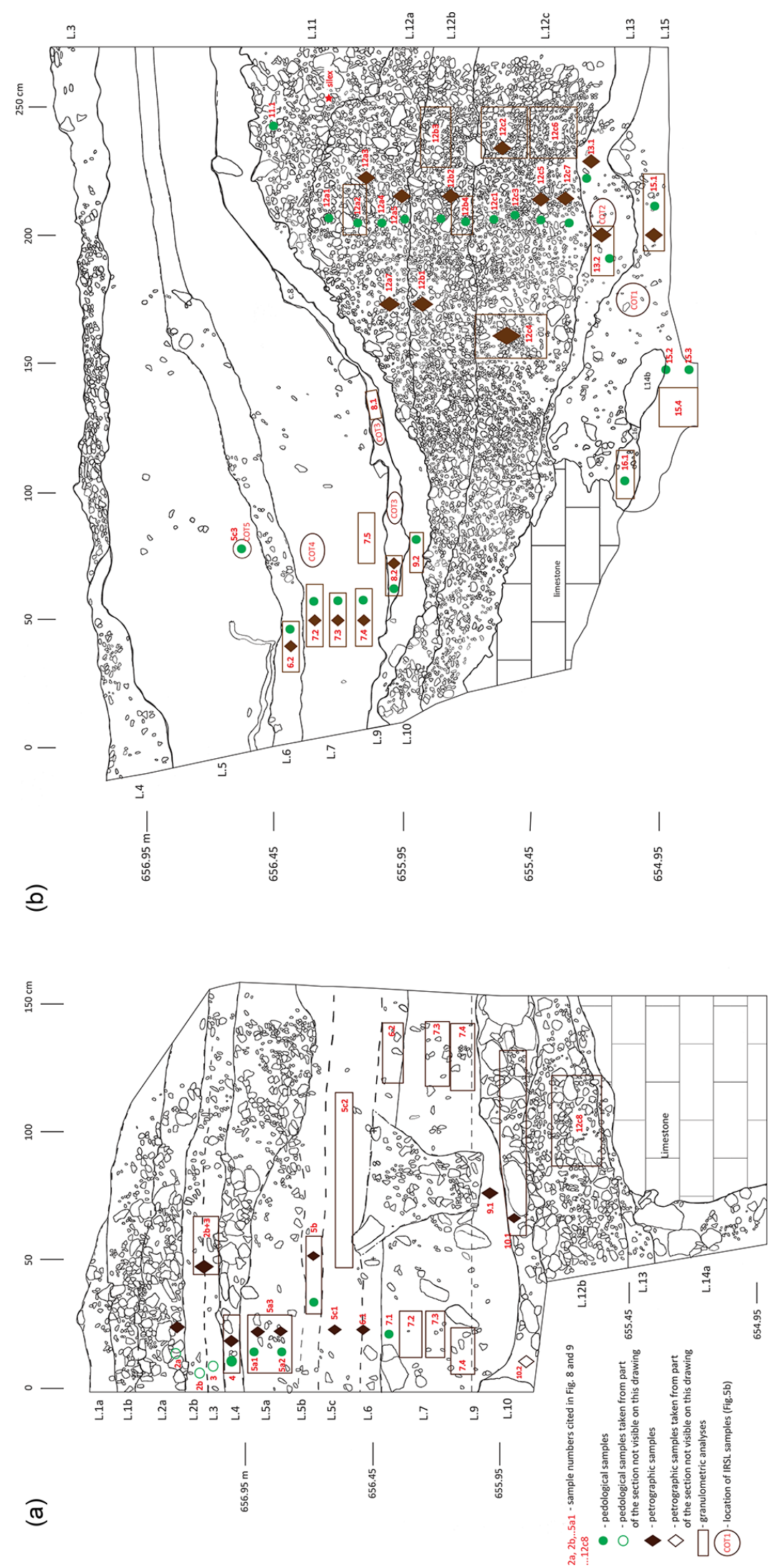

Figure 5. Drawing of sampled sections: morphology of the layers and localisation of the samples mentioned in this paper. (a) Section 1 (ST1); (b) Section 2 (ST2). 


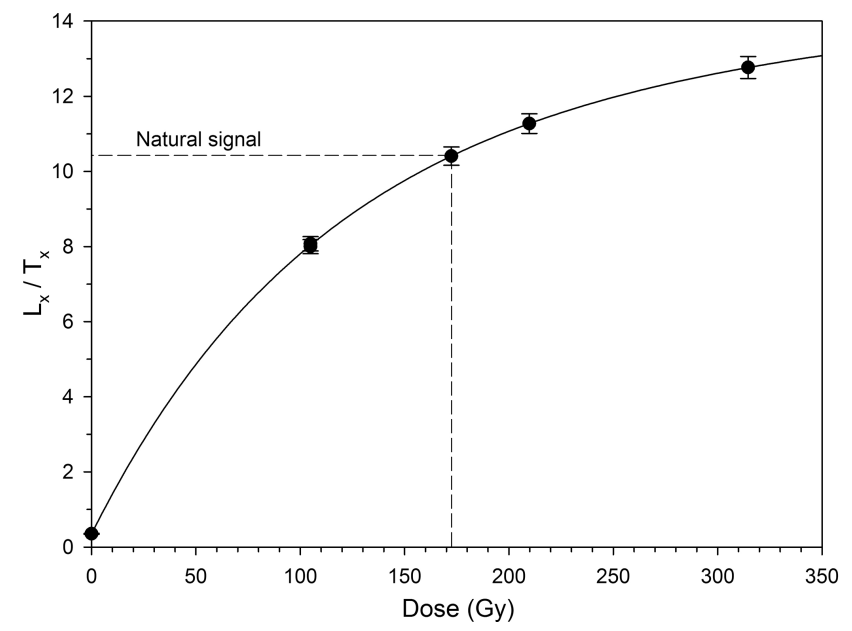

Figure 6. Example of a normalised dose response curve for an aliquot of sample COT-3 IR-50.

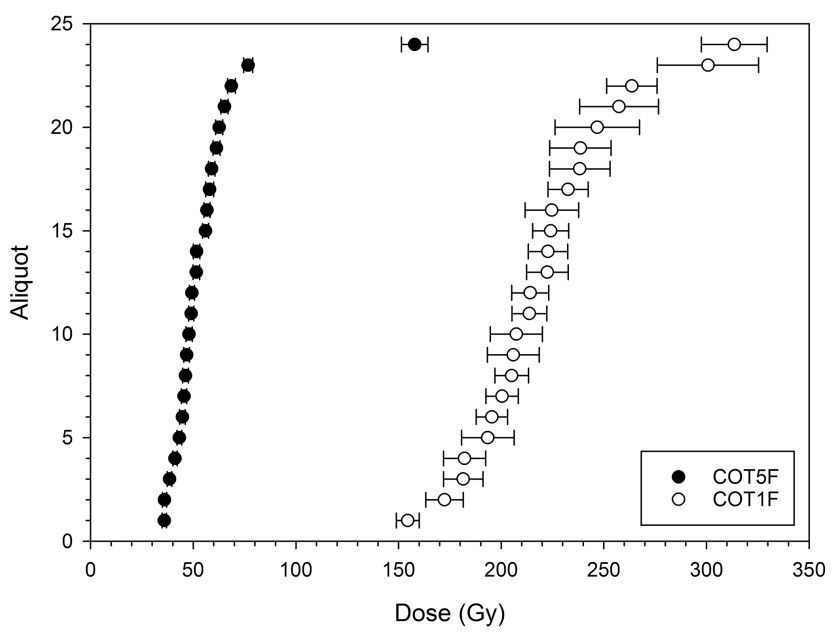

Figure 7. Dose distribution plots exemplified for IR-50 of two samples.

ferent behaviour of IR-50 and pIR-225. For sample COT3 , we received average values of $5.99 \pm 1.39$ Gy (IR-50) and $54.25 \pm 18.03 \mathrm{~Gy}$ (pIR-225), and this represents apparent residual ages of ca. 3 and $27 \mathrm{ka}$, respectively. The third test aims at investigating the stability of different signals with time. For this, four previously measured aliquots were used and the normalised luminescence signal $\left(L_{x} / T_{x}\right)$ was monitored with different time intervals between irradiation and measurement (Auclair et al., 2003), with a maximum of $5500 \mathrm{~s}$. This results in average $g$ values of $1.5 \pm 0.7 \%$ per decade for IR-50 and of $0.5 \pm 0.3 \%$ per decade for pIR-225, based on four replicate measurements for COT-3.

Material for dose rate determination was taken around the position sampled for measuring $D_{\mathrm{e}}$. During sampling it was attempted to collect material representative for the depositional context by taking between 500 and $1000 \mathrm{~g}$. The ma- terial was dried, crushed, and homogenised. High-resolution gamma spectrometry was carried out at VKTA Rossendorf e.V. (by Detlev Degering). To investigate for radioactive disequilibrium different decay products in the uranium decay chain are compared (cf. Zander et al., 2007). Dose rate and ages were calculated using Adele software (designed by Detlev Degering). Average sediment moisture was estimated on the measurement of the present-day water content and the geological setting (Table 4). These values roughly correspond to the porosity evaluated through the observation of undisturbed samples in thin sections. Nevertheless, as discussed below, a wide range of environmental and depositional changes occurred during the sedimentation and in situ evolution of the analysed sequence. In addition to the humidity inherent to the karstic environment, the water content of samples was affected by (i) COT1 evolved mostly in dry conditions; although during its own deposition there was surely some water flow. Moreover, during deposition of the overlying sediments (L.14 and L.13) it was subject to some (1000 years?) years of water/ice saturation. (ii) COT2 was deposited by water (Figs. 4b, 5b and Table 5), but it is impossible to estimate how long it was water saturated; the overlying deposit (L.12) was mainly deposited by solifluction on frozen ground with no evidence of water flow and was thus mostly dry. (iii) COT.3, COT.4, and COT.5 are water-laid deposits and they were affected by freeze-thaw processes probably for several thousand years. Conversely, water saturation was absent after deglaciation. Taking all these elements into consideration and in order to avoid circular reasoning, the luminescence age was calculated including a large uncertainty (Table 4) to account for potential moisture changes in the past.

Cosmic dose rate calculation follows Prescott and Hutton (1994) corrected for geographic position and using a rock cover of $10 \mathrm{~m}$. For feldspar, an internal K content of $12.5 \pm 1.0 \%$ was used (Huntley and Baril, 1997), supported by measurements from the Swiss Plateau (Gaar et al., 2014). The efficiency of alpha particles in causing radiation damage (alpha efficiency, $a$ value) was assumed to be $0.05 \pm 0.01$, following Preusser (1999) and Preusser and Kasper (2001) as the geographically closest $a$ value assessments.

\section{Results}

\subsection{Lithic artefacts}

The lithic assemblage studied so far (flint and flaked quartzite) is composed of 457 pieces, most of them found in the gravelly layer (L.12), while only a few have been gathered from the brown layer (L.15) (Table 1). The majority of these finds (428 objects) originate from excavations performed between 1916 and 1918 (Dubois and Stehlin, $1932 / 1933$,) but data regarding the vertical and horizontal distribution of these artefacts have not been processed so far. During the 2016 excavations in addition to the chips (see be- 


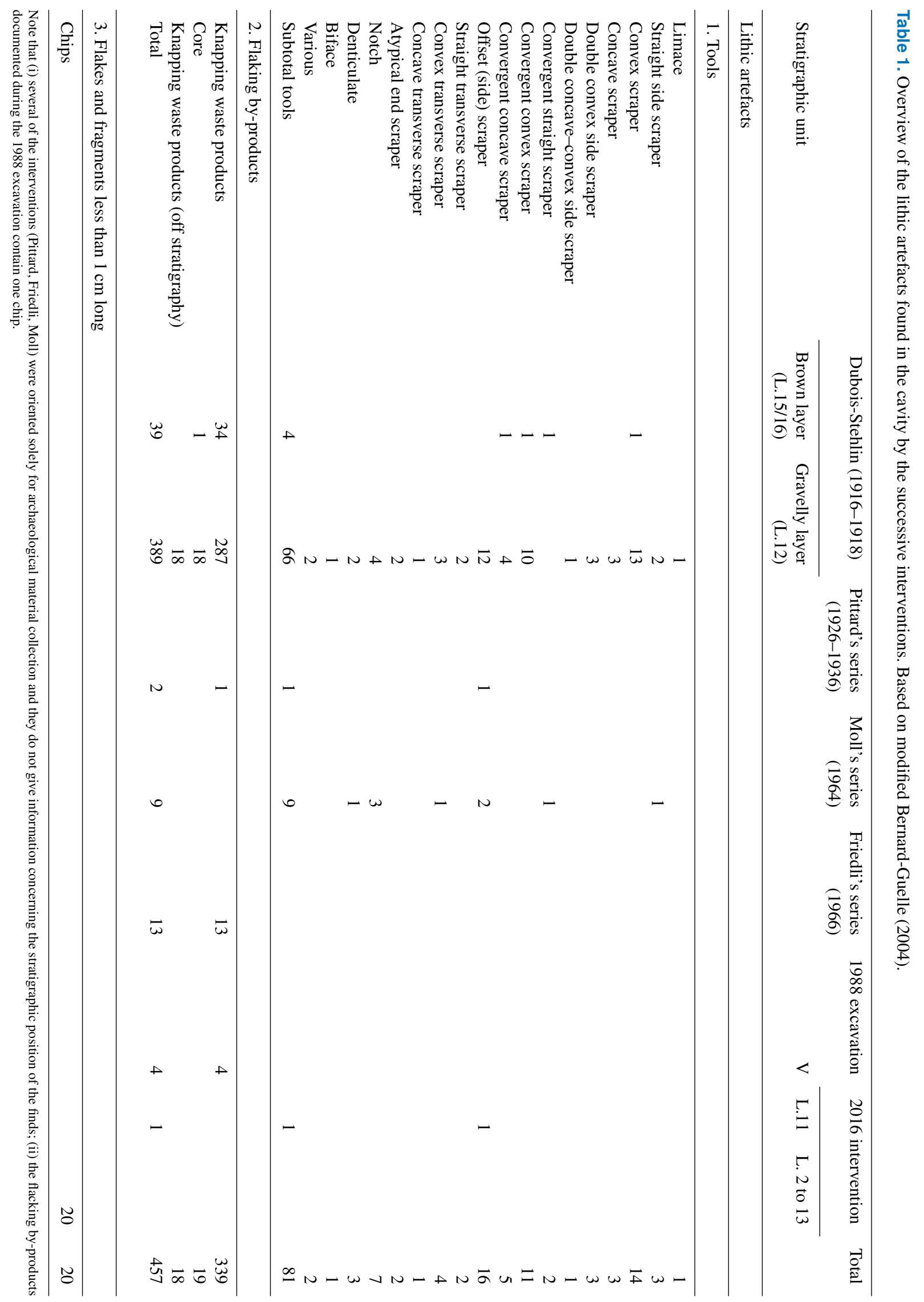


low) only one flint object was found, a canted scraper with a thinned base (Chauvière et al., 2018a). The 1988 and 2016 operations revealed the presence of 1-2 cm long chips (flakes and fragments of flakes, Table 1). These artefacts were absent in the inventories compiled before 1988, when no sieving was performed. These chips indicate that flaking operations and manufacturing and sharpening of tools were probably conducted in the cave and/or close to its entrance. Moreover, some chips have a curved profile and their distal part conserves a portion of the dorsal surface of the original flake. These two observations constitute diagnostic criteria to identify them as retouch flakes. The 20 chips of 2016 excavations were found in layers $10,12 \mathrm{~b}, 12 \mathrm{c}$, and 13 of sections 1 and 2 (Figs. 4a, b, 5a, b), but also in layers 2, 3, 4, and 5 of section 1. For L.2 to L.5 these chips possibly originate from overlaying deposit due to pedoturbation processes. Indeed, L.1 is known to contain Holocene archaeological remains (Dubois and Stehlin, 1932/1933). Thus, based on the available data we suggest that these are likely related to Tardiglacial or Holocene use of the site. Finally, it is worthwhile to mention that the layer enclosing the scraper found in 2016 (L.11) contained only a few bone fragments and no flint chips.

To summarise, the lithic industry of Cotencher cave with its numerous scrapers (63 of 83 tools) can be classified as Mousterian Charentian of oriental Quina type, characterised by a discoidal debitage (non-Quina) (Bernard-Guelle, 2004). Nevertheless the scarcity of "scalariform" retouches and the high number of canted scrapers (16), some of them with thinned bases, indicate a certain distinction compared with the typical Charentian sites (ibid).

\subsection{Faunal remains}

The assemblage of faunal remains discussed here concerns the finds collected during the 1916-1918 excavations and originates from the two main archaeological find layers (L.15 and L.12), with a high number of pieces and rich in species (Table 2). It is composed of herbivores, carnivores, and omnivores that indicate a wide variety and sometimes divergent ecological background, from temperate to severely cold. The simultaneous presence of reindeer and wild boar, for example, two species with very contrasting ecological backgrounds, suggests a complex environmental and sedimentary history (Le Tensorer, 1998). The interpretation of the environmental significance of this assemblage is still incomplete, as the data processing concerning their horizontal and vertical distribution is still in progress. Nevertheless, the available information already indicates a polygenetic depositional history. A closer look at the rodent species gives some more details, as L.15 (brown layer) contains both arctic-steppic and forest species, while L.12 (gravelly layer) only contains heliophile and forest species (Table 3).

Noteworthy is the fact that the studied bone assemblages did not yield any faunal remains with undeniable cut marks.
Indeed, the long bone fracture surfaces are typical dry bone fractures that are characteristic for bones whose breaking is not interesting for nutrition or those that are frequently found in natural accumulations (in open-air sites or in caves) for which the question of anthropogenic contribution does not arise. In the current state of research, the main criteria for identifying human activity (Castel et al., 2012) appear to be absent from the Cotencher bone assemblages. As a consequence, with the available data there are no arguments to infer a synchronous accumulation of the silex and the bone finds. Similar conclusions have been obtained for several other Mousterian sites situated in mountain environments and raise the question of the reasons for human passage in these areas marginal to the main occupation territories. The absence of hunting and food consumption evidence has been explained as an indication of sites preferentially used for tool preparation (Castel et al., 2012).

\subsection{Luminescence dating}

The performance of IR-50 and pIR-225 is generally good (e.g. low recuperation, recycling values close to unity), and even for the oldest samples signal levels do not approach saturation (Fig. 6). In most samples, the distribution of $D_{\mathrm{e}}$ values is skewed and overdispersion exceeds 0.20 , implying the presence of at least some partial bleaching. This is illustrated in Fig. 7, showing a tight distribution for IR-50 of sample COT5, with one prominent outlier at the upper edge. For IRSL of sample COT1, an overdispersion of 0.15 and a Gaussian-like distribution are interpreted to represent complete resetting of the IR-50 signal prior to deposition in this particular sample. As this represents the only well-bleached sample in the data set, its value was used as input parameter sigma_b when applying the minimum age model (MAM; Galbraith et al., 1999) to all other samples. Even after applying MAM, mean De values of pIR-225 are much higher compared to IR-50 and not in agreement with radiocarbon dating available for the upper part of the sequence (Table 4). The pIR-225 ages are also internally inconsistent. This is interpreted to represent high residual levels in the pIR-225 signal at the time of deposition that are masked by averaging effects in the multigrain feldspar aliquots. With respect to incompletely bleached samples, this may result in age overestimation even when the MAM is applied because signals from incompletely bleached grains mask the signals of well-bleached grains on the aliquots. Such an observation is not unexpected considering the literature (e.g. Buylaert et al., 2012; Lowick et al., 2012, 2015) and the results of the bleaching experiment carried out here. The pIR-225 estimates are hence not considered in further discussion. While signal instability could affect the IR-50, the measured $g$ values are rather small, at the lower edge of values reported by Lowick et al. (2012). As these authors observe uncorrected IR-50 ages in good agreement with independent dating control, we also refrain from carrying out fading corrections. 
Table 2. Overview of the vertebrate faunal remains according to their stratigraphic position, based on the material documented by Dubois and Stehlin (1932/1933). Based on Le Tensorer (1998, p. 103-106).

\begin{tabular}{|c|c|c|c|}
\hline \multicolumn{2}{|r|}{ Taxonomy } & \multirow[t]{2}{*}{ Brown layer (L.15/16) } & \multirow[t]{2}{*}{ Gravelly layer (L.12) } \\
\hline Order & Family or species & & \\
\hline \multirow{16}{*}{ Carnivora } & Ursus arctos & $x$ & $x$ \\
\hline & Ursus spelaeus & $x$ & $x$ \\
\hline & Panthera spelaea & $x$ & $x$ \\
\hline & Panthera pardus & $\times$ & $x$ \\
\hline & Lupus lupus & $x$ & $x$ \\
\hline & Cuon alpinus & $x$ & $x$ \\
\hline & Gulo gulo & & $x$ \\
\hline & Lynx cf. pardina & $x$ & $x$ \\
\hline & Lynx lynx & & $x$ \\
\hline & Alopex lagopus & & $\times$ \\
\hline & Vulpes corsac & $\times$ & $x$ \\
\hline & Vulpes vulpes & $x$ & $x$ \\
\hline & Felis sylvaticus & & $x$ \\
\hline & Mustela putorius & $x$ & \\
\hline & Mustela nivalis & $\times$ & \\
\hline & Martes martes & $x$ & $x$ \\
\hline \multirow{3}{*}{ Perissodactyla } & Equus sp. & $x$ & $\times$ \\
\hline & Dicerorhinus kirchbergensis & & $\times$ \\
\hline & Coelodonta antiquitatis & $x$ & \\
\hline \multirow{6}{*}{ Artiodactyla } & Sus scrofa & $x$ & $x$ \\
\hline & Cervus elaphus & $x$ & $x$ \\
\hline & Rangifer tarandus & $x$ & $x$ \\
\hline & Bovidae & $x$ & $x$ \\
\hline & Capra ibex & $x$ & $x$ \\
\hline & Rupicapra rupicapra & $\times$ & $\times$ \\
\hline Lagomorphs & Lepus timidus & $x$ & $x$ \\
\hline \multirow{16}{*}{ Rodentia } & Marmota marmota & $x$ & $x$ \\
\hline & Arvicola sp. & & $x$ \\
\hline & Arvicola terrestris & $x$ & \\
\hline & Microtus gregalis & $x$ & \\
\hline & Microtus nivalis & $x$ & $x$ \\
\hline & Microtus raticeps & $x$ & \\
\hline & Microtus arvalis & $x$ & \\
\hline & Clethrionomys rutilus & $\times$ & \\
\hline & Dicrostonyx torquatus & $x$ & $x$ \\
\hline & Sciurus vulgaris & $\times$ & \\
\hline & Martes ermina & $x$ & $\times$ \\
\hline & Cricetus cricetus & $\times$ & \\
\hline & Allocricetus bursae & $\times$ & \\
\hline & Eliomis quercinus & $\times$ & $x$ \\
\hline & Glis glis & $x$ & $x$ \\
\hline & Apodemus sylvaticus & $\times$ & $\times$ \\
\hline Soricidae & & $x$ & \\
\hline \multirow{4}{*}{ Chiroptera } & Miniopterus schreibersi & & $x$ \\
\hline & Plecotus auritus & $\times$ & \\
\hline & Myotis myotis & $x$ & $\times$ \\
\hline & Rhynolophus ferrum equinum & $\times$ & \\
\hline
\end{tabular}


Table 2. Continued.

\begin{tabular}{|c|c|c|c|}
\hline \multicolumn{2}{|r|}{ Taxonomy } & \multirow[t]{2}{*}{ Brown layer (L.15/16) } & \multirow[t]{2}{*}{ Gravelly layer (L.12) } \\
\hline Order & Family or species & & \\
\hline \multirow{17}{*}{ Aves } & Aquila chrysaetos & & $x$ \\
\hline & Pyrrhula pyrrhula & $x$ & \\
\hline & Anatidae & & $\times$ \\
\hline & Pyrrhocorax graculus & $x$ & $x$ \\
\hline & Pyrrhocorax pyrrhocorax & $\times$ & $\times$ \\
\hline & Falco peregrinus & & $x$ \\
\hline & Bucephala clandula & & \\
\hline & Tetrao uragallus & & $x$ \\
\hline & Corvus corax & $x$ & \\
\hline & Bubo bubo & & $x$ \\
\hline & Lagopus mutus & & $x$ \\
\hline & Apus melba & & $x$ \\
\hline & Turdus sp. & & $\times$ \\
\hline & Picus canus & & $\times$ \\
\hline & Fringilla montifringilla & & $x$ \\
\hline & Tetrao tetrix & $x$ & \\
\hline & Tetrao urogallus & & $x$ \\
\hline Amphibia & & $x$ & $x$ \\
\hline Pisces & & $x$ & $x$ \\
\hline
\end{tabular}

Table 3. Summary of the ecological significance of the rodent remains according to their stratigraphic position. Based on Le Tensorer (1998, Tables I and II, modified).

\begin{tabular}{lrr}
\hline Ecological groups & $\begin{array}{r}\text { Brown layer } \\
\text { (L.15/16) } \\
(\%)\end{array}$ & $\begin{array}{r}\text { Gravelly layer } \\
(\text { L.12) } \\
(\%)\end{array}$ \\
\hline Arctic species & 35 & 0 \\
Steppic species & 14 & 0 \\
Heliophilic species & 8 & 39 \\
Forest species & 40 & 71 \\
Wet species & 2 & 0 \\
Total & 100 & 100 \\
\hline
\end{tabular}

Regarding dose rate determination, we found very similar values for the three samples from the upper part of the sequence, which implies a quite homogenous composition of the sediment. Furthermore, the results for different isotopes of the uranium decay chain are in good agreement, indicating the absence of significant radioactive disequilibrium (Table 4). Interestingly, the concentration of dose-rate-relevant isotopes is about $50 \%$ higher in the two lower samples, in particular in sample COT2. Furthermore, both samples show evidence for radioactive disequilibrium, indicated by different values observed for U-238, Ra-2226, and Pb-210 (Table 4). The observed surplus in U-238 is likely the result of carbonate precipitation rich in this isotope but devoid of the daughter isotopes (Ra-2226 and $\mathrm{Pb}-210)$, as these are not solvable in water. The pronounced changes in environmental conditions in the past inhibit proper modelling of U uptake. Carrying out a correction for $\mathrm{U}$ uptake appears inappropriate considering the uncertainties related to the environmental history but our screening implies it will not exceed $10 \%$ with regard to age calculation (cf. Preusser and Degering, 2007).

\subsection{Sedimentary dynamics and site formation}

The stratigraphic succession comprises 16 layers (L.1 to L.16), most of which are strongly calcareous (Table 5). For accessibility reasons only L.5 to L.16 were investigated in detail; therefore the discussion below will mainly concern these layers. Despite careful searching, no charcoal fragments were found in the analysed sections. A summary of the recent observations and comparison with former stratigraphic interpretations is shown in Fig. 3.

\subsubsection{Layers 16 and 15 and the brown layer}

The sediments labelled as L.15 and L.16 represent the upper part of the cave's oldest archaeological find layer known as the brown layer (Fig. 3). This upper part is characterised by involutions. Due to technical restrictions, a merely $20 \mathrm{~cm}$ thick band of this deposit could be investigated discontinuously over $3 \mathrm{~m}$; therefore as reasoned in Table 5 the two facies of this layer are discussed together. L.15 and L.16 have a reddish (L.15) or black (L.16) colour and relatively high organic carbon values $(0.8 \%-0.9 \%)$, while the $\mathrm{CaCO}_{3}$ is markedly low $(11 \%-14 \%)$, revealing significant pedo- 


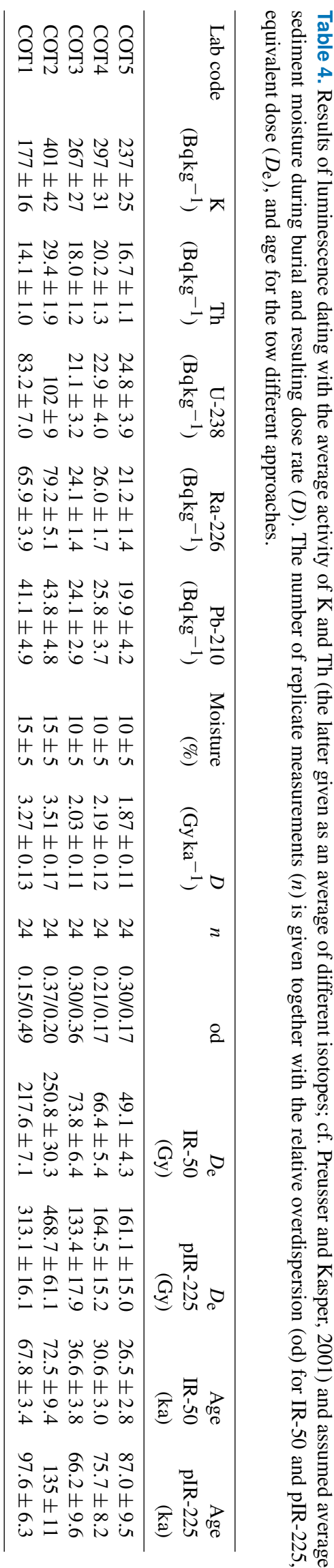

genetic processes (Fig. $8 \mathrm{~b}$ and Table 5). The fine material is fluffy. Our study of the $>8 \mathrm{~mm}$ fraction indicates that it is composed of weathered bedrock limestone with some (ca. $8 \%$ ) rolled limestone gravel (Fig. 8a).

The underlying brown layer is present all over the cave and fills up the natural depressions inside the cavity, with a maximal thickness of $1.5 \mathrm{~m}$ (Fig. 2). The coarse fraction is absent in its lower part and varies between $10 \%$ and $50 \%$ in its upper part (Rentzel, 1990, and Table 5). Locally large limestone blocks probably originating from the ceiling are also present (Dubois and Stehlin, 1932/1933, Rentzel, 1990). A few small (ca. $1 \mathrm{~cm}$ ) alpine pebbles and a notable amount of sand grains of alpine origin are attributed to reworking of older glacier deposits (Dubois and Stehlin, 1932/1933). The fine material is characterised, at least locally, by traces of stratification (Dubois and Stehlin, 1932/1933). X-ray mineralogy reveals some calcite and quartz grains in the bulk samples, while the clay fraction is characterised by the marked presence of mica, kaolinite, and pedogenetic phyllosilicates. The later data are interpreted as an indication of a relationship to previous Eemian soil cover that occurred in the surroundings (Rentzel, 1990; Adatte et al., 1991). The fine material contains common phosphate-rich impregnations or nodules with values of ca. $12 \%$ to $74 \% \mathrm{CaCO}_{3}\left(\mathrm{PO}_{4}\right)_{2}$ (Dubois and Stehlin 1932/1933; Rentzel, 1990). Rare occurrences of charcoal fragments were mentioned by Rentzel (1990).

All these data suggest that the layer is the result of compound accumulation processes: (i) deposition inside the cave of a soil formed under and in front of the rock shelter, (ii) breakdown and in situ weathering of bedrock, and (iii) important input of biogenic phosphorus-rich organic material (decomposed faunal remains and coprolites and/or bat guano). The significant quantity of weathered, but not rolled, cave bear bones scattered throughout the layer (Dubois and Stehlin, 1932/1933) and the high amount of faunal remains (Table 2) argues for in situ phosphorus accumulation. The IRSL age for the upper part of this deposit is $67.8 \pm 3.4 \mathrm{ka}$ (COT1, Table 4).

\subsubsection{Layer 14}

This stratified sediment, composed of alternating sandy, clayey, or heterometric gravelly strata, has been observed by Rentzel (1990) both close to the entrance of the cavity and in its inward side. During the 2016 work we distinguish only a few thin discontinuous lenses of this layer, while towards the inner part of the cavity, explored in 2017, a stratified deposit up to $57 \mathrm{~cm}$ thick was observed (Table 5). In this inward part, large limestone blocks (at least 40 or $20 \mathrm{~cm}$ ) are present at the upper part of this deposit. X-ray mineralogy of the bulk samples indicates a high amount of quartz and feldspar, while interstratified phyllosilicates and kaolinite in the clay fraction are less common compared to the underlying layer (Adatte et al., 1991). The sedimentological characteristics suggest deposition by running water. 
Table 5. Brief descriptions of the sediments.

\begin{tabular}{|c|c|c|c|c|}
\hline $\begin{array}{l}\text { Layer } \\
\text { no. }\end{array}$ & Brief description & $\begin{array}{l}\text { Coarse } \\
\text { fraction }\end{array}$ & $\begin{array}{r}\text { Thickness } \\
(\mathrm{cm})\end{array}$ & $\mathrm{HCl}$ \\
\hline 1 & $\begin{array}{l}\text { Angular and more or less platy limestone fragments }(2-14 \mathrm{~cm} \text { diameter }) \\
\text { in a granular humiferous silty matrix. The lower part of the layer the } \\
\text { fine material is less humiferous and there are travertine- and stalagmite- } \\
\text { like concretion fragments. Common present-day roots. Lower boundary } \\
\text { is sharp. }\end{array}$ & u.p. $40 \%$; 1.p. $50 \%$ & 38 & \pm \pm \pm \\
\hline 2 & $\begin{array}{l}\text { White (5Y 8/1.5) strongly porous granular silt with common angular } \\
\text { limestone fragments }(5-12 \mathrm{~cm} \text { diameter) in its upper layer and a few } \\
\text { small ( } 2-3 \mathrm{~cm} \text { diameter) limestone fragments in its lower part. Abundant } \\
\text { present-day roots in its lower part. Lower boundary is gradual. }\end{array}$ & $\begin{array}{l}\text { u.p. } 30 \%-40 \% \text {; } \\
\text { 1.p. } 2 \%-5 \%\end{array}$ & 20 & +++ \\
\hline 3 & $\begin{array}{l}\text { Grey homogeneous clayey-sandy silt. Observed only in section } 1 \text {. Lower } \\
\text { boundary is gradual. }\end{array}$ & & $8-10$ & ++ \\
\hline 4 & $\begin{array}{l}\text { Slightly brownish clayey-sandy silt with common angular rock frag- } \\
\text { ments ( } 3-5 \mathrm{~cm} \text { diameter). Lower boundary is gradual but laterally shows } \\
\text { pocket-like morphology. }\end{array}$ & $30 \%$ & $10-30$ & \\
\hline 5 & $\begin{array}{l}\text { Light grey to white }(5 \mathrm{Y} \text { 7.5/2) sandy, slightly clayey silt. Separated in } \\
\text { three layers based on the coarse material. From up down: for L.5a the } \\
\text { upper part has a few angular limestone gravels more or less vertically } \\
\text { oriented; for L.5b the middle part has almost no coarse fraction and is } \\
\text { more sandy with small }(0.2-0.6 \mathrm{~cm} \text { diameter) stratified gravel; L.5c has } \\
\text { a homogenous lower part with rare calcareous gravel }(2-3 \mathrm{~cm} \text { diameter). } \\
\text { Its lower part fills up the gully that erodes L. } 12 \text { and that is partially filled } \\
\text { by L. } 7 \text { to L. } 10 \text {. Compact, brittle, and fine ( } 1 \mathrm{~mm} \text { thick) lamellar structure } \\
\text { in the upper part, with coarser lamellar (up to } 1 \mathrm{~cm}) \text { in depth. Lower } \\
\text { boundary is sharp. }\end{array}$ & $\begin{array}{l}\text { u.p. } 10 \% ; \text { m.p. }<1 \% \text {; } \\
\text { 1.p. } 2 \%-3 \%\end{array}$ & $20-70$ & +++ \\
\hline 6 & $\begin{array}{l}\text { Former gravel level: } 0.5-11 \mathrm{~cm} \text { in depth angular or sub-rounded lime- } \\
\text { stone gravels. A few of the gravels are still at this contact. Most of them } \\
\text { are situated along vertical fissures until the deeper part of the layer. One } \\
\text { cluster of them suggests an ice wedge cast. Lower boundary is sharp. }\end{array}$ & & 10 & \\
\hline 7 & $\begin{array}{l}\text { Homogeneous, light grey ( } 5 \text { Y } 7.5 / 3 \text { ) silty to clayey silty sediment. More } \\
\text { and more clayey in depth. Compact and brittle. Large platy structure } \\
\text { which becomes angular blocky in depth. Partially fills up the channel } \\
\text { marked by the underlying layers. Lower boundary is sharp with involu- } \\
\text { tions of the underlying layer. }\end{array}$ & $20 \%-30 \%$ & $20-60$ & +++ \\
\hline 8 & $\begin{array}{l}\text { White, well-sorted, fine bleached sand. Upper limit with involutions. } \\
\text { Lower boundary is sharp. }\end{array}$ & 0 & $5-10$ & +++ \\
\hline 9 & $\begin{array}{l}\text { Grey-brownish }(2.5 \mathrm{Y} 7 / 2) \text { clayey sediment. Stratified with involutions } \\
\text { and angular clayey soil fragments incorporated. Former studies describe } \\
\text { a chaotic related distribution of these fragments. Plugs the lower part of } \\
\text { a depression created by the deposition L.10, while it eroded L.12. Lower } \\
\text { boundary is sharp. }\end{array}$ & 0 & $10-15$ & +++ \\
\hline 10 & $\begin{array}{l}\text { Angular calcareous boulders }(10-20 \mathrm{~cm} \text { diameter }) \text { and rounded/sub- } \\
\text { rounded calcareous gravels present in the lower part of the depression } \\
\text { eroding the underlying layer } 12 \text {. Lower boundary is sharp. }\end{array}$ & $100 \%$ & 15 & \\
\hline
\end{tabular}


Table 5. Continued.

\begin{tabular}{|c|c|c|c|c|}
\hline $\begin{array}{l}\text { Layer } \\
\text { no. }\end{array}$ & Brief description & $\begin{array}{l}\text { Coarse } \\
\text { fraction }^{\mathrm{a}}\end{array}$ & $\begin{array}{r}\text { Thickness } \\
(\mathrm{cm})\end{array}$ & $\mathrm{HCl}$ \\
\hline 11 & $\begin{array}{l}\text { Heterometric, rather compact sediment composed of limestone and one } \\
\text { crystalline rock fragment in a slightly humiferous light greyish brownish } \\
\text { silty }(2.5 \mathrm{Y} 7.5 / 2) \text { fine material. The fine material resembles layer } 9 \text {. Some } \\
\text { of the gravels are rounded, while the others are angular. This sediment } \\
\text { is only present at the entrance of the cavity. An artefact was found at its } \\
\text { lower boundary. Lower boundary is sharp and irregular. }\end{array}$ & $40 \%-50 \%$ & $15-50$ & +++ \\
\hline
\end{tabular}

12 Gravelly layer contains angular, sub-rounded, and rounded gravels in a humiferous silty-sandy fine material. Its upper part is eroded at the level of section 1. Frequent present-day roots. Subdivided in three sub-layers based on the size and amount of gravels and the colour of the fine material.

12a has somewhat more brownish (2.5Y 5.5/3), less humiferous fine material and seems to be more compact than the underlying $12 \mathrm{~b}$ and $12 \mathrm{c}$; coarse fraction: $2-5 \mathrm{~cm}$ diameter;

$12 \mathrm{~b}$ has somewhat more sandy and darker (2.5Y 5-5.5/3), more humiferous fine material. The coarse fraction $(3-5 \mathrm{~cm}$ diameter) is more abundant and several of the stones are rather rounded. Some bone fragments. The gravels give an impression of sloping towards the interior of the cavity. Some of the rock fragments are vertically oriented.

$12 \mathrm{c}$ has rather sandy fine material and is slightly lighter coloured $(2.5 \mathrm{Y}$

$5 / 4)$ compared with the overlying. The coarse material is less abundant and somewhat finer (mostly less than $1 \mathrm{~cm}$ diameter; a few $2-3 \mathrm{~cm}$ diameter) compared with the overlying layers. Granular structure. Lower boundary is gradual.

13 Light brown (2.5Y 6.5/4), silty to silty clayey sand with small gravel ( $\pm 3 \mathrm{~mm}$ diameter). Seems to be the fill of depressions cut in the underlying L.15. Lower boundary is sharp and irregular.

14 The entrance of the cavity is represented by a fine sandy, stratified, yellowish-greenish (2.5Y 7.5/1.5-3) well-sorted deposit present as irregular spots at the upper part of layer 15 or incorporated in its upper part. Observed in a very limited area. In some of the fragments internal involutions could be observed.

Inside the cavity (2017 intervention) is represented by a stratified deposit

12a: $30 \%$

$70-200^{\mathrm{b}}++$ to +++

12b: $50 \%$

12c: $20 \%-30 \%$

$5 \%-10 \% \quad 15-20+++$

0

$3-10+++$ composed of the following. (i) Lower part includes sandy and clayey layers containing mostly angular limestone pebbles in their upper part; (ii) middle part includes alternating grey and white, well-sorted sandy layers followed by sandy-silty heterometric deposit containing about $40 \%$ rolled gravels $(0.5-1 \mathrm{~cm}$ diameter); (iii) upper part includes stratified clayey deposit having lamellar structure covered by well-stratified white sandy deposit. (iv) In its upper part there is a level of at least $40 \mathrm{~cm}$ of large angular limestone blocks. Lower boundary is sharp.

15/16 Orange sandy silt (10YR 7.5-4.5/3-6) with a few rather weathered calcareous rock fragments $(5-8 \mathrm{~cm}$ diameter). Fluffy and very friable. The upper surface has involutions and this irregular upper surface is highlighted by a $1 \mathrm{~cm}$ thick iron impregnation. Observed over a very limited length and only over a $20 \mathrm{~cm}$ thickness. On a very restrained surface its upper part is slightly darker (7.5YR 3.5/4) and this was designated as L.16. The technical restrictions of the field intervention inhibited further observation.

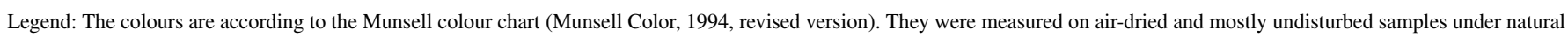
light.

u.p.: upper part; m.p.: middle part; l.p.: lower part.

Reaction with $\mathrm{HCl}: \pm \pm \pm$ : very strong; +++ : strong; ++ : weak; + : very weak.

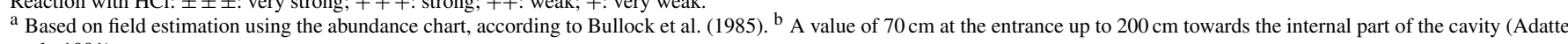
et al., 1991). 
Table 6. Petrographic and morphologic descriptions of the various rock fragment groups.

\begin{tabular}{|c|c|c|c|}
\hline Code* & Brief description & Comments & Coarse fraction group* \\
\hline Ref. I & $\begin{array}{l}\text { Light grey to slightly beige, very compact, } \\
\text { indurated, fine crystalline limestone. Undulat- } \\
\text { ing to rough (microkarst-like) external surfaces } \\
\text { with a thin discontinuous white, slightly pow- } \\
\text { dery coating. Locally thin hard, hard, and gran- } \\
\text { ular crust. Cutting external edges. }\end{array}$ & $\begin{array}{l}\text { Sampled outside of the cavity: limestone bank } \\
\text { forming the ceiling of the rock shelter. Upper } \\
\text { strata. }\end{array}$ & \\
\hline Ref. III & $\begin{array}{l}\text { Dark grey, compact, indurated, finely crys- } \\
\text { talline limestone. Undulating external surfaces } \\
\text { with a very thin white crust. Cutting external } \\
\text { edges. }\end{array}$ & As above: lower part of the middle strata. & \\
\hline Ref. V & $\begin{array}{l}\text { Light grey to yellowish whitish, very compact, } \\
\text { indurated, fine crystalline limestone. Rough ex- } \\
\text { ternal surfaces covered by a slight powdery } \\
\text { white crust and organic matter. }\end{array}$ & $\begin{array}{l}\text { Isolated limestone block situated in front of the } \\
\text { cavity, covered my mosses and litter. }\end{array}$ & \\
\hline Ref. VI & $\begin{array}{l}\text { Brownish grey, very compact, indurated, fine } \\
\text { crystalline limestone. Rough external surfaces } \\
\text { covered by a white, irregular, rather hard crust. } \\
\text { Some Fe impregnations towards its external } \\
\text { rim. }\end{array}$ & $\begin{array}{l}\text { Sampled inside the cavity: limestone outcrop } \\
\text { situated on the floor of the cavity, at the level } \\
\text { of sections } 1 \text { and } 2 \text {. }\end{array}$ & \\
\hline Ref. VIII & $\begin{array}{l}\text { Beige to yellowish grey, very compact, in- } \\
\text { durated, fine crystalline limestone. Undulating } \\
\text { to smooth external surfaces with an irregular } \\
\text { thin white crust. Resembling to Ref. IV(3) }\end{array}$ & $\begin{array}{l}\text { Sampled inside the cavity: limestone outcrop } \\
\text { on the floor situated towards the inner third of } \\
\text { the cavity. }\end{array}$ & \\
\hline GF1 & $\begin{array}{l}\text { Strongly porous, tuff-like } \mathrm{CaCO}_{3} \text { nodules and } \\
\text { platy, rather angular, compact } \mathrm{CaCO}_{3} \text { crust } \\
\text { fragments. }\end{array}$ & & $\mathrm{A}$ \\
\hline GF2 & $\begin{array}{l}\text { Light grey to dark grey, very compact, in- } \\
\text { durated finely crystallised angular to subangu- } \\
\text { lar rock fragments. Undulating surfaces cov- } \\
\text { ered by a thin indurated } \mathrm{CaCO}_{3} \text { crust. Rather } \\
\text { sharp edges. }\end{array}$ & Resemble Ref. II and III. & A \\
\hline
\end{tabular}


Table 6. Continued.

\begin{tabular}{|c|c|c|c|}
\hline Code & Brief description & Comments & Coarse fraction group \\
\hline GF3 & $\begin{array}{l}\text { Light grey to whitish, very compact, indurated, } \\
\text { fine crystallised angular to subangular rock } \\
\text { fragments. Undulating external surfaces cov- } \\
\text { ered by thin, indurated, white } \mathrm{CaCO}_{3} \text { crust. }\end{array}$ & Resemble Ref. I. & A \\
\hline GF4 & $\begin{array}{l}\text { Very compact, indurated, sub-rounded to sub- } \\
\text { angular limestone rock fragments. Rough and } \\
\text { porous external surfaces (alteration, dissolution } \\
\text { of fossils) covered by thin, hard, white crust. } \\
\text { Under this crust: brownish grey, fine crystalline. } \\
\text { Locally more brownish hard precipitations. }\end{array}$ & Resemble Ref. VI. & A \\
\hline GF5 & $\begin{array}{l}\text { Rather porous weathered rock fragments at } \\
\text { least partially covered by orange-brownish } \\
\text { (phosphorus?) precipitation crust. Sometimes } \\
\text { sandy aspect. Sometimes part of them is } \\
\text { whitish, suggesting a least weathered lime- } \\
\text { stone. Weak to moderate reaction with } \mathrm{HCl} \text {. }\end{array}$ & $\begin{array}{l}\text { Weathered and phosphorus impregnated rock } \\
\text { fragments (Ref. VIII). }\end{array}$ & A \\
\hline GF6 & $\begin{array}{l}\text { Subangular to sub-rounded limestone frag- } \\
\text { ments having a rough white external surface } \\
\text { with partially preserved microkarst features. In- } \\
\text { side compact light grey. }\end{array}$ & Might correspond to Ref. I & $\mathrm{B}$ \\
\hline GF7 & $\begin{array}{l}\text { Subangular to sub-rounded, polished surfaced, } \\
\text { indurated, strongly compact limestone frag- } \\
\text { ments. White at the surface, yellow-brownish } \\
\text { grey fine crystallisation inside. }\end{array}$ & Resemble Ref. IV and VIII. & $\mathrm{C}$ \\
\hline GF8 & $\begin{array}{l}\text { Sub-rounded light grey yellowish limestone } \\
\text { fragment with smooth surfaces suggesting } \\
\text { rolling processes. }\end{array}$ & Resemble Ref. I. & $\mathrm{C}$ \\
\hline GF9 & Bright white rounded fine sandstone gravels. & Might be rolled fragments of Ref. VII. & $\mathrm{C}$ \\
\hline GF10 & $\begin{array}{l}\text { Brownish grey, rounded limestone gravel with } \\
\text { smooth/polished surfaces. }\end{array}$ & & $\mathrm{D}$ \\
\hline GF11 & $\begin{array}{l}\text { Grey to dark grey, rounded to sub-rounded } \\
\text { limestone or fine sandstone gravels with smooth } \\
\text { surfaces. }\end{array}$ & & $\mathrm{D}$ \\
\hline GF12 & $\begin{array}{l}\text { Greyish white, laminated fine sandstone grav- } \\
\text { els. }\end{array}$ & & $\mathrm{D}$ \\
\hline GF13 & Rounded Alpine rock fragments. & & $\mathrm{D}$ \\
\hline GF14 & $\begin{array}{l}\text { Strongly rolled } 1-2 \mathrm{~cm} \text { diameter gravels. } \\
\text { Mostly limestones, but rare alpine rock } \\
\text { fragments. }\end{array}$ & & $\mathrm{D}$ \\
\hline GF15 & $\begin{array}{l}\text { Small }( \pm 1 \mathrm{~cm}) \text { irregular } \mathrm{CaCO}_{3} \text { concretions, } \\
\text { resembling loess dolls. }\end{array}$ & & $\mathrm{D}$ \\
\hline GF16 & $\begin{array}{l}\text { Dark grey to black angular limestone. Thin } \\
\mathrm{CaCO}_{3} \text { crust. }\end{array}$ & $\begin{array}{l}\text { Might correspond to Ref. III, but it might be a } \\
\text { fragment of a black limestone. }\end{array}$ & $\mathrm{E} ?$ or $\mathrm{D} ?$ \\
\hline GF17 & $1-2 \mathrm{~cm}$ large, angular calcite crystals. & & $\mathrm{E}$ \\
\hline GF18 & Angular yellowish small limestone fragments. & Might be lithic artefacts. & $\mathrm{E}$ \\
\hline
\end{tabular}


(a)

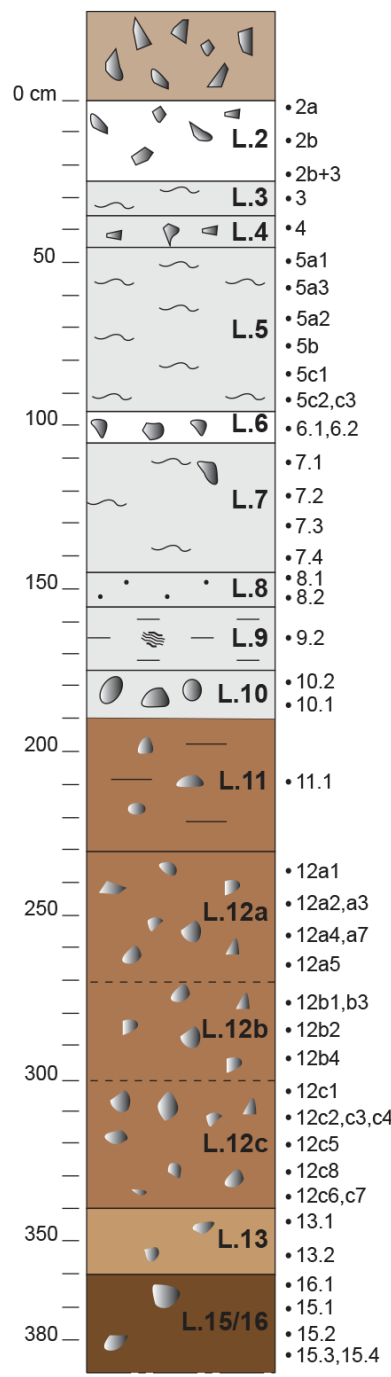

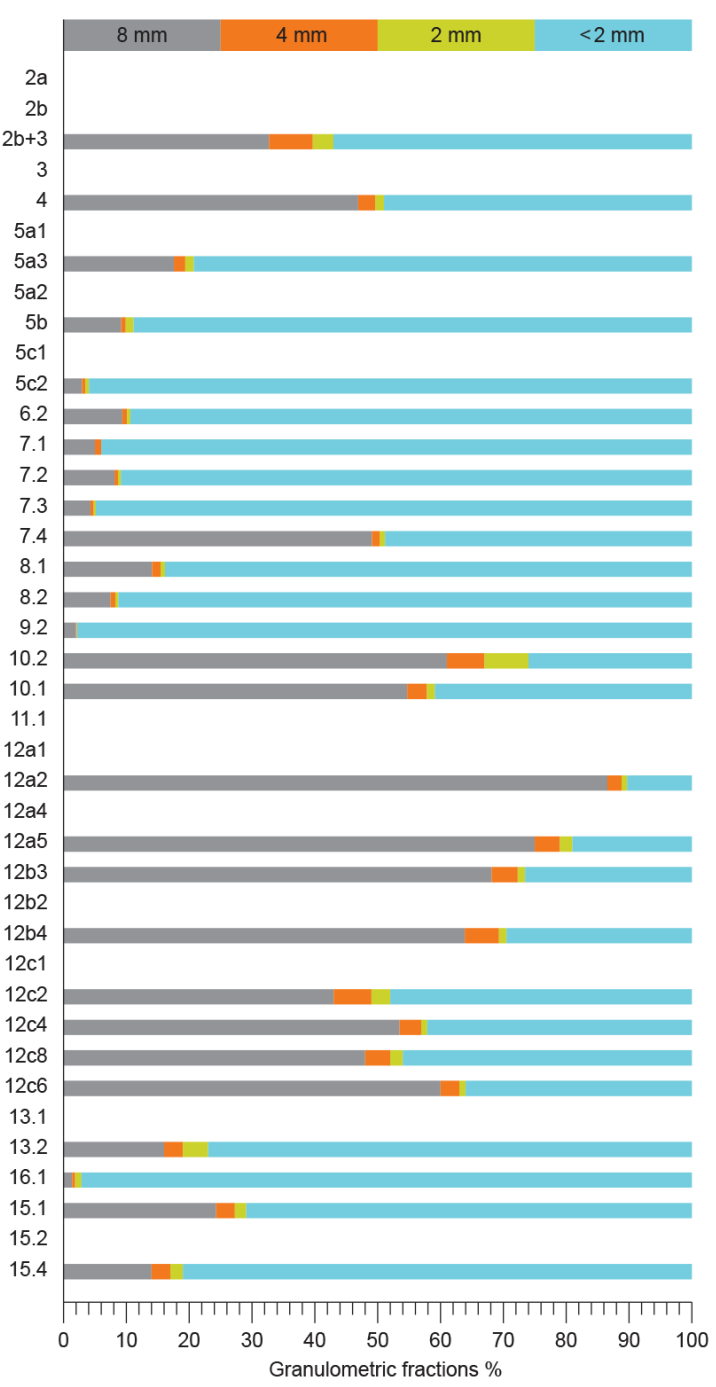

(b)

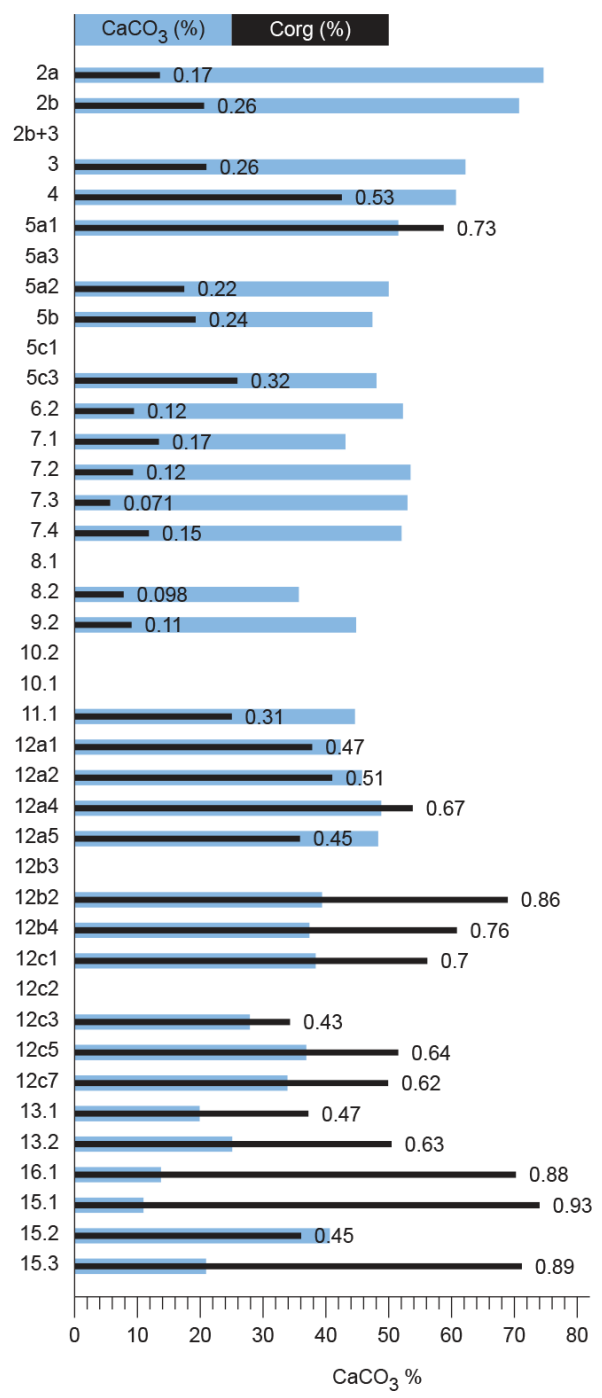

Figure 8. Variation in granulometric and chemical soil characteristics throughout the studied layers. (a) Granulometry. (b) Variation in organic carbon and $\mathrm{CaCO}_{3}$ content. Legend: $2 \mathrm{a}$ to 15.4 - sample numbers; their location is presented in Figs. 4a, b and 5a, b.

\subsubsection{Layer 13}

This heterometric relatively finely textured sediment has been observed in a gully-like depression in section 2, towards the entrance of the cave. The $8 \mathrm{~mm}$ fraction is mainly composed of slightly reworked local limestone fragments, but in the fine gravel fraction $(1-2 \mathrm{~cm})$ small quantities of rounded limestone pebbles of various origins and one rounded quartzite were detected (Figs. 8a and 9). Field and laboratory observations and the analytical data (organic carbon and $\mathrm{CaCO}_{3}$ content, Fig. 8b) suggest that it is a partial reworking of the underlying L.15 and L.16 with some fresh sediment input. The latter is suggested by the rounded small gravels and the relatively higher $\mathrm{CaCO}_{3}$ content compared to the underlying L.15 and L.16. The morphology in the channel-like depression suggests torrential flows at this external part of the cavity. The sections examined do not permit us to state whether L.13 and L.14 are the result of two clearly distinct sedimentary events or if they are the different sediment facies deposited during the same landscape destabilisation phase. This layer has been dated to $72.5 \pm 9.4 \mathrm{ka}$ (COT-2, Table 4) but this sample shows a high overdispersion, implying the presence of partial bleaching. This is in contrast to COT-1, which appears to be well bleached. Altogether, the environmental proxy data and IRSL dating of this lower part of the studied sequence imply correlation to the periods of severe cooling of the S3 stadial (MIS 4). 

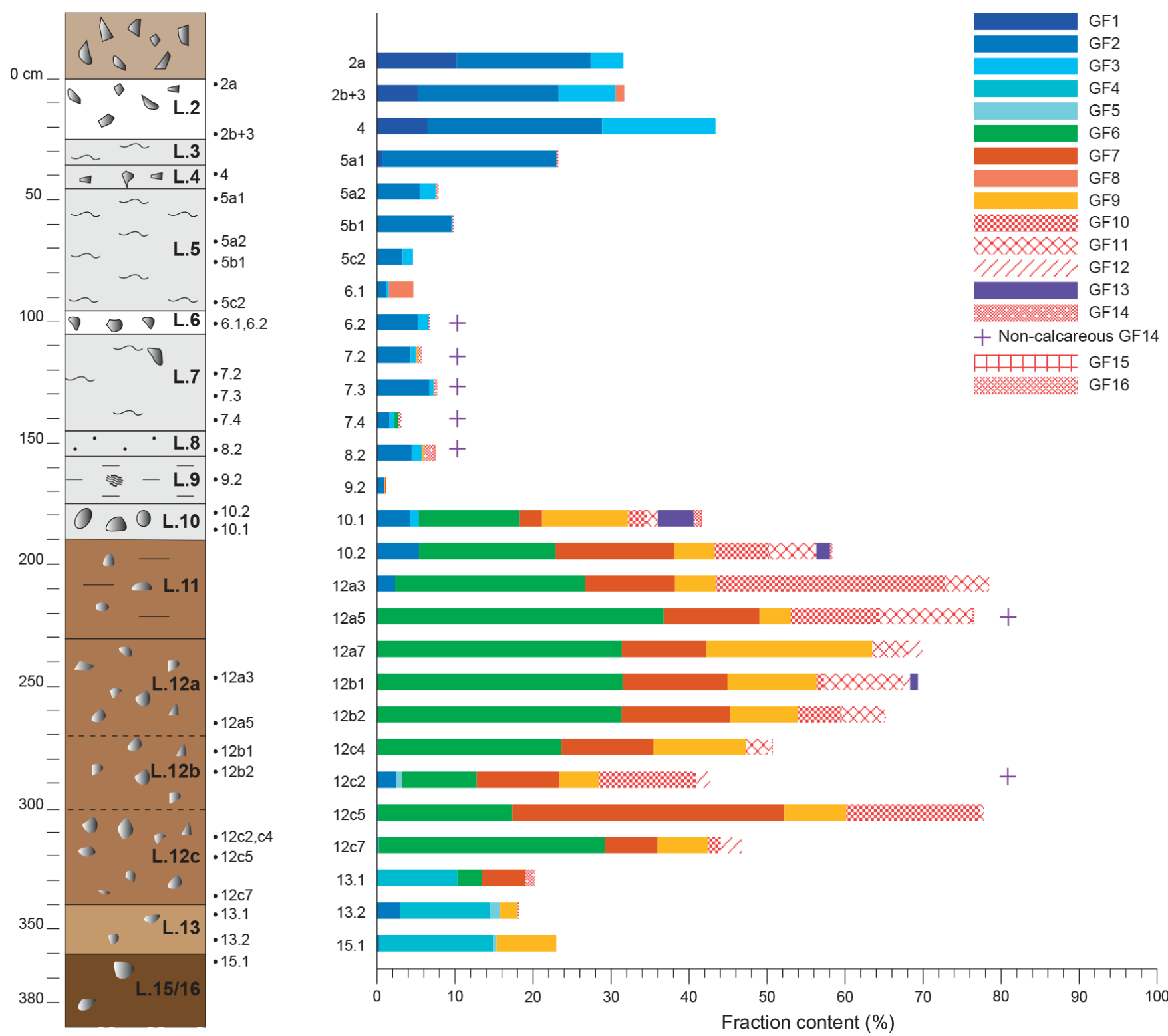

Figure 9. Petrographic composition of the more than $8 \mathrm{~m}$ fraction of selected samples. Legend: 2a to 15.1 - sample numbers; their location is presented in Fig. 5a and b. GF: gravel fractions as described in the methods and Table 6. GF1 to GF5: fresh rock fragments originating from the limestone layers hosting the cave (group A); GF6: pebbles similar to limestone strata enclosing the cave but at least shortly transported (group B); GF7 to GF9: pebbles similar to the limestone strata enclosing the cave, but strongly rounded (group C); GF10 to GF16: pebbles not present in the strata enclosing the cave (group D). Note the presence of non-calcareous gravels of GF14 is indicated by a cross as their quantity is too small to be visible on the graph.

\subsubsection{Layer 12}

This rich coarse material, up to $180 \mathrm{~cm}$ thick, sediment (Figs. 4a, b, 5a, b, 8a; Table 5) is present all over the cavity (Dubois and Stehlin, 1932/1933; Rentzel, 1990). The coarse fraction varies between $50 \%$ and $92 \%$ and the $>8 \mathrm{~mm}$ fraction, composed mainly of 3-8 cm large pebbles, dominates in this deposit (Fig. 8a). Petrographic observations (Fig. 9) indicate that throughout this deposit the coarse material is composed of (i) more or less rolled limestone fragments similar to the limestone banks hosting the cavity and (ii) rolled limestone and sandstone pebbles that are allochthonous. Part of the gravel has a powdery, and thus weathered, external part, while others are more polished and little weathered. Noncalcareous components are very rare and are represented by one ca. $3 \mathrm{~cm}$ large rolled schist or gneiss fragment (sp.12.5) and a few rolled ca. $5-10 \mathrm{~mm}$ pebbles. The variability in petrography and morphology of the calcareous coarse fraction has already been highlighted by Dubois and Stehlin 
(1932/1933). They also stated that the alpine components are very rare, all rounded, and dominated by quartzite, with a few gneiss pebbles.

The $<2 \mathrm{~mm}$ fraction is more important in the lower part of the deposit (30\%-40\% in L.12c and L.12b) and it decreases in the upper part (less than $20 \%$ in L.12a). Throughout L.12 this fine material is rather rich in $\mathrm{CaCO}_{3}$, but except in the upper part of the layer (L.12a), values are less than $40 \%$. The organic carbon values show some variability, but generally they are rather high (Fig. 8b). In the lower part of the deposit (L.12c and L.12b) organic contents are highest and increases upward (L.12b), while in the uppermost part (L.12a) these values are generally lower, although certain variability is present. The $\mathrm{CaCO}_{3}$ content, on the contrary, is markedly lower in the lower part of the deposit (L.12c and L.12b) and increases towards the top (L.12a). All this suggests that the fine material constituting this unit has undergone noticeable pedogenetic processes that had a more important fingerprint in the lower part of the deposit (L.12c and L.12b).

The clay and silt fractions are dominated by mica (Adatte et al., 1991). Weathered clay minerals (interstratified phyllosilicates) are present mainly in the lower part of the deposit while in the upper part chlorite increases in parallel to the quasi-fading of the interstratified constituents.

Bone fragments are present all over the layer and all through the cavity; some of them are strongly rolled, part of them are clearly reworked, and part of them seem to be rather fresh (Dubois and Stehlin, 1932/1933). Although former studies mention the presence of charcoal (Rentzel, 1990), we did not find any despite the large number of samples sieved. No in situ fireplaces have been observed so far but sieving revealed pebbles bearing traces of heating. A concentration of burned rock fragments, associated with a fresh lithic tool, has been documented towards the upper part of this deposit, during the 2017 campaign. This feature will be studied during a later phase of this project.

To summarise, all these data suggest a complex environmental history recorded in this deposit. The heterogeneous and allochthonous coarse fractions indicate that part of the sediment source was originally situated outside the cavity. The traces of pedogenetic processes all over this layer indicate that this sediment evolved as a soil outside the cavity. Eventually the heterometric soil and its faunal and artefact constituents were deposited inside the cavity during several depositional phases. The chronological setting of these processes is specified by the stratigraphic position of L.12 (Fig. 3) and will be discussed below.

\subsubsection{Layer 11}

This heterometric coarse-material-rich (Table 5), rather compact sediment is present only towards the entrance of the cavity and it wedges out towards the inside. Due to technical reasons it was only briefly examined and sampled during the 2016 operations. The fine material is moderately humifer- ous and rather strongly calcareous (Fig. 8b), while the coarse fraction is composed of rounded and angular limestone fragments and at least one rounded pebble of alpine origin (Table 5). The poorly sorted nature of this deposit suggests deposition by mass movement. Similarly to L.12, the origin of the sediment is most probably related to a deposit situated earlier at the cavity entrance, but as indicated by the chemical soil characteristics this deposit was little affected by the pedogenetic processes. The presence of the alpine rock fragment can be explained as either originating from reworked glacial sediment or it could be related to human activity.

\subsubsection{Layer 10}

This sediment is composed of mostly rolled, but also angular, coarse gravel, blocks of autochthonous and allochthonous limestone, and a few alpine pebbles (Table 5 and Figs. 8a, 9). Earlier studies also described a more heterometric facies of this deposit with an irregularly surfaced gravelly layer composed of rounded limestone and alpine pebbles, rich in bone fragments, and having a sandy-silty matrix (Rentzel, 1990). As for the non-calcareous components, the largest rounded pebble $(9 \mathrm{~cm})$ found in L.10 $(\mathrm{sp} .10 .1)$ is proven to be a stone tool, while the others are $2-4 \mathrm{~cm}$ large rounded to sub-rounded quartzite and angular schist fragments accounting for $3 \%$ of the coarse material of sample 10.2 (Figs. 8a, 9). As argued for L.12 and L.11 above, the few non-calcareous components are most likely reworked from sediments that already existed in the region. The clay mineralogy of the fine sediment is similar to L.12, but no interstratified, pedogenetic minerals are present in the clay fraction (Adatte et al., 1991). L.10 has been observed at the bottom of the depression cut in the L.12. This gully - traversing the rock shelter parallel with the main valley - removed, at its deepest part, at least $40 \mathrm{~cm}$ of the gravel-rich L.12 (Fig. 4b).

These elements indicate that an important water flow traversed this landscape position and reworked and disturbed sediments towards the entrance of the cavity. It eroded the fine material of L.12 and rolled and re-sedimented part of its coarser fraction, including the bone fragments. Limestone fragments from the cavity fallen due to frost shattering completed the sediment body accumulated.

\subsubsection{Layer 9}

This layer is a highly calcareous, stratified, finely textured clayey, silty sediment. The few coarse components found by sieving (Fig. 8a) are probably related to underlying L.10. In some parts the clayey band is discontinuous and chaotically oriented. The layer partially fills the channel cut before the deposition of L.10 (Figs. 4b, 5a, b), but it is also present in the inner parts of the cavity (Rentzel, 1990). These sedimentary features indicate fine material deposition by low energy flow and decantation in a pond environment. The presence of standing water in highly porous rock and at this landscape 
position further argues for a frozen landscape. The chaotically oriented clayey bands indicate freeze-thaw processes affecting this layer. The absence of pollen in the test samples (Bezat, 1990), the low organic carbon content, and the absence of the organic layers in the sequence are in good agreement with a vegetation-free glacial environment.

\subsubsection{Layer 8}

This strongly calcareous, stratified, well-sorted, fine sandy layer with some gravels (Figs. 4b, 8a; Table 5) indicates an episode of significant water flow. The size and morphology of the coarse fraction (Fig. 8a) indicate episodes of more energetic water flow and also some cryoclastic rock fall from the ceiling during the deposition of this layer. The involutions observed at its surface are related to freeze-thaw processes occurring during and/or after the deposition of layer 7. The IRSL age of this layer indicates deposition around $36.6 \pm 3.8 \mathrm{ka}$ (COT3, Table 4).

\subsubsection{Layer 7}

This strongly calcareous, lightly coloured, clayey silty deposit (Table 5 and Figs. 4a, b, 8a, b) has been described at the entrance of the cavity, but earlier studies suggest that it is probably present all over the cave (Dubois and Stehlin, 1932/1933; Rentzel, 1990). It coarsens upward. Traces of stratifications have been reported by Rentzel (1990). It is a rather compact and brittle sediment with platy structure. In the sections investigated it can be up to $40 \mathrm{~cm}$ thick and represents the upper fill of the gully eroding the upper part of the L.12. The coarse fraction, except its lowest part, represents less than $10 \%$ (Fig. 8a) and is mainly composed of angular rock fragments similar to the limestone strata hosting the cavity. A low abundance (a few grains per sample), but systematic presence, of small (ca. $5 \mathrm{~mm}$ ) rounded alpine pebbles was observed (Fig. 9). These are probably related to the presence of older alpine material in the surroundings. The organic carbon content is very low, among the lowest measured in this stratigraphic sequence (Fig. 8b). Screening for palynological content revealed an absence of pollen (Bezat, 1990), whereas mineralogical analyses document the lack of weathered minerals (Adatte et al., 1991). In former studies this and the overlying layer (L.5) have been described as one single deposit (Dubois and Stehlin1932/1933; Rentzel, 1990). Our subdivision is based on the occurrence of a gravel layer (L.6) on top of L.7 and an ice wedge cast filled with these gravels (Figs. 4a, 5a). The IRSL age of the upper part of the layer is $30.6 \pm 3.0 \mathrm{ka}$ (COT4, Table 4).

\subsubsection{Layer 6}

This layer is composed of mostly angular limestone pebbles and some smaller blocks resembling the limestone strata hosting the cavity. It is present as (i) a discontinuous gravel layer occurring on top of L.7 and (ii) dispersed or concen- trated vertical stones inside the underlying L.7 (Figs. 4a, 5a). The morphology of the latter is interpreted as a former ice wedge cast and fill of the former cryodesiccation features. All these elements indicate the absence of fine sediment input, strong freezing conditions favourable of permafrost, ice wedge formation, and cryoclastic breakdown of the surrounding limestone walls.

\subsubsection{Layer 5}

This strongly calcareous sandy, slightly clayey silt is present all over the cavity (Table 5 and Rentzel, 1990), with its maximal thickness of about $60 \mathrm{~cm}$ towards the entrance (Fig. 2b). It appears rather homogeneous but shows some stratification and a distinct platy structure (Table 5 and Rentzel, 1990). In addition some faint vertical cryodesiccation features could also be observed. Except for the upper part, coarse material is scarce (Fig. 8a) and composed of almost exclusively angular, local limestone fragments (Fig. 9). The organic carbon content is low except for the uppermost sample (Fig. 8b), which is likely contaminated by present-day roots. Mineralogical analyses indicate the absence of weathered minerals (Adatte et al., 1991).

Sedimentation of this layer indicates that water-flow processes were regularly active again at this landscape position. The texture suggests that part of the fine material might be of aeolian origin. The platy structure, the cryodesiccation fissures and the cryoclasted rock fragments incorporated in the sediment witness a particular cold environment during the accumulation of this deposit. IRLS dating of the sample from the lower part of the layer indicates an age of $26.5 \pm 2.8 \mathrm{ka}$ (COT5, Table 4).

\subsubsection{Layers 3 and 4}

These strongly calcareous heterometric sediments, with abundant angular limestone fragments in L.4 (Figs. 4a, 5a, 9), were found only at the entrance of the cavity. The common angular limestone fragments in L.4 suggest important cryoclastic breakdown of the cavity roof that possibly indicates cold climatic phases. The lack of chronological, field, and analytical data does not permit a discussion of the deposition processes and environmental significance of these layers.

\section{Discussion}

As recognised already by former scholars in the first quarter of the twentieth century (Dubois and Stehlin, 1932/1933) the sedimentary sequence of the Cotencher cave is an outstanding record of the environmental changes that occurred during the Late Pleistocene. Regional climatic fluctuations (Fig. 10) are also documented in different sections of the alpine foreland (Preusser, 2004) and in the Jura Mountains (Cupillard et al., 2015). The deposits of the Cotencher cave reinforce 

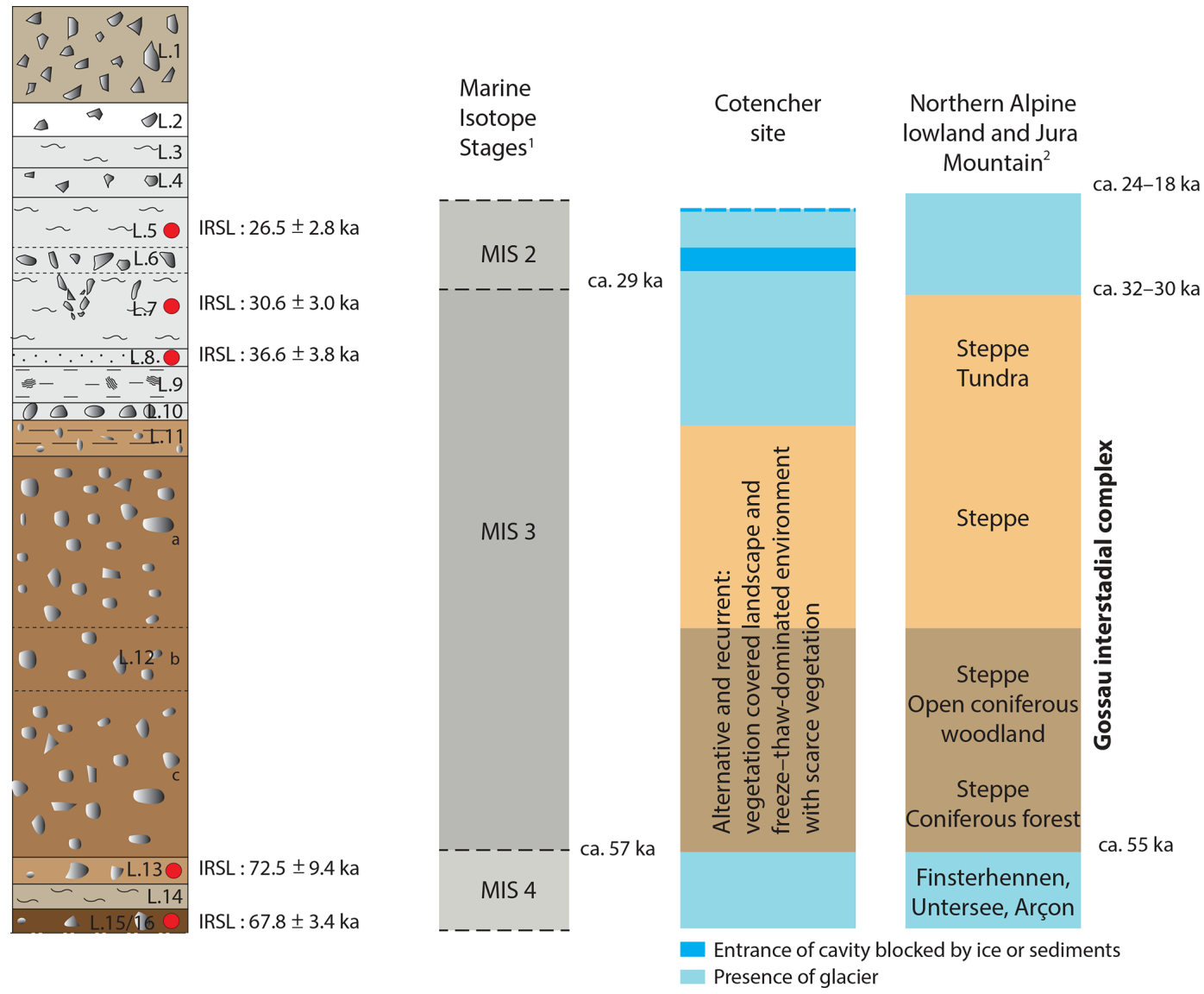

Figure 10. Syntheses of the Cotencher data in comparison with the regional chronological and palaeoenvironmental record. ${ }^{1}$ based on Lisiecki and Raymo (2005). ${ }^{2}$ based on Preusser (2004), Ivy-Ochs et al. (2008), Cupillard et al. (2015), and Bichet et al. (2016).

some of the former environmental records and permit us to further decipher the complexity of Jura and Alpine glacier dynamics.

\subsection{Early last glacial: evidence of landscape destabilisation}

Based on mineralogical arguments, the brown layer present in the lower part of the stratigraphic sequence has been interpreted as sediment originating from Eemian soil (Adatte et al., 1991). Its spatial (vertical and horizontal) distribution (Fig. 2b) suggests the presence of a reasonably large sediment platform in front of the cave and under the rock shelter. Pedogenetic processes transformed this sediment and the resulting rather weathered soil has been subsequently reworked into the cave. The observations available so far do not permit an exhaustive discussion about the deposition processes, but the stratified sandy layer described by Dubois and Stehlin (1932/1933) clearly suggests at least some water flow towards the cavity, while the large limestone blocks witness gravitational accumulations. The important quantity of biogenic phosphorus (Dubois and Stehlin, 1932/1933; Rentzel, 1990) and the presence of numerous cave bear (Ur- sus speleous) bones together with the presence of animal bones indicating both steppe and forest vegetation cover (see Sect. 4.2) suggest slow sediment build-up over a long time span and sediment accumulation during several depositional phases. Involutions in the upper part of this layer may reflect cryoturbation processes but could also be related to faunal turbation, such as digging by bears in order to prepare hibernation dens (e.g. at the rock shelter of Tanay Sur-les-Creux; Braillard et al., 2004). Larger sections would be needed to formulate a trustworthy interpretation.

The L.15 observed and analysed in this work represents only the uppermost part of this stratigraphic unit known as the brown layer (Fig. 3). For this part of the sequence the IRSL chronology suggests reworking processes around $67 \mathrm{ka}$ (see discussion below). As a result we can only deduce that the accumulation of the brown layer containing part of the Mousterian artefacts occurred during several phases of the early Last Glacial, but this can be detailed only through more suitable sections and further dating. 


\subsection{Evidence of glacier processes around $70 \mathrm{ka}$}

In the lower part of the studied sequence several converging sedimentary and chronological facts indicate the presence of a glacier environment in the surroundings of Cotencher cave. First of all, layers L.14 and L.13 suggest water flow processes both at the entrance and towards inner parts of the cavity. The presence of running water despite the steep slopes and strongly permeable environment both inside cavity and under the rock shelter at about $140 \mathrm{~m}$ above the river valley bottom implies that something kept up the water. The geomorphological context as described above suggests the presence of a neighbouring glacier during the deposition of these sediments. The high $\mathrm{CaCO}_{3}$ content of the various sublayers, their low organic carbon content, and the cyroclasted coarse components (Table 5) further sustain the hypothesis of a cold environment characterised by sparse or absent vegetation cover. Altogether, the environmental proxy data and IRSL dating of this lower part of the studied sequence (COT1 and COT2, Table 4) imply correlation to the periods of severe cooling with the S3 stadial (MIS 4). This evidence is further completed by the information provided by the sedimentary data recorded in L.12. Indeed the coarse fraction of this layer reveals that the sediment source of this deposit is not only limited to physical breakdown of the limestone hosting the cavity. As such, the thickness of this layer, the wide variety of stone fragments, their morphology, and particularly the allochthonous and rolled pebbles (Fig. 9) reveal the presence of a rather thick and heterometric sediment outside the cavity that was originally deposited, at least partially, by water. Once more, the evidence of water flow, depositing coarse material in the studied geomorphological context, strengthens the hypothesis of the presence of a glacier. Layer L.12 was deposited after $67 \mathrm{ka}$. Moreover, before its deposition it has undergone pedogenetic processes. Therefore we can conclude that the deposition of the sediment source of L.12 in the surroundings of the cavity also occurred during the severe cold period of S3 stadial (MIS 4).

To summarise, during the $\mathrm{S} 3$ stadial the studied landscape was occupied by ice masses and thick associated deposits. In this environment the seasonal meltwater deposited the finer sediments of L.14 and L.13 inside the cavity and possibly reworked the upper part of the brown layer, sampled as L.15 here. Similarly accumulation of heterometric sediment (source of L.12) at the entrance of the cave and on the surrounding slopes was related to ice-marginal debris supply resulting in the deposition of lateral moraine or kame terraces. The petrographic data suggest that this glacier was of local (Jura Mountains) origin. The very few alpine elements can be well explained as reworking of deposits of older glacial material, which extended westward beyond the LGM (Campy, 1992) and were also mapped in the neighbourhood of the studied region (Méia and Becker, 1976; Pasquier et al., 2013).
This climatic cooling of MIS 4 is rarely evidenced in the regional terrestrial record. Two sites witnessing glacier advances have been reported: in the northern Alpine foreland at Finsterhennen glacier-outwash deposits have been dated to about $70 \mathrm{ka}$ (Preusser et al., 2007), while in the Jura Mountains recent studies of an outcrop at Arçon also described glacio-fluviatile sediments situated under organic sediments dated to ca. $48 \mathrm{ka}$ and interpreted as possibly deposited during this period (Bichet et al., 2016). As such the Cotencher sedimentary record represents additional evidence for this rarely recorded climatic event in terrestrial context and its importance lies also in its geographical position, situated between the above-mentioned locations (Fig. 1).

It is interesting to mention that the hypothesis of glacial sedimentation in front of the cavity has already been formulated by Dubois and Stehlin (1932/1933). Similar to our reasoning, they tried to understand the presence of the wide variety gravels in the couche à galets. They concluded that only the presence of a glacier, different from the one known for the main Würmian with an alpine source, could explain waterlaid deposits high above the valley bottom. Based on the scientific data of their time, they interpreted this glacier activity ("Areuse precursor glaciation") as representing a cooling that occurred before the LGM-dated Rhone glacier conquered the Alpine foreland and the slope of the Jura Mountains (Dubois and Stehlin, 1932/1933).

\subsection{Alternation of pedogenetic and cryogenic processes during MIS 3}

Layers L.12 and L.11 witness evolution outside and recurrent sediment transport towards the cavity. The organic matter accumulation and the associated $\mathrm{CaCO}_{3}$ content trends, the slight weathering of the limestone fragments, and the notable presence of pedogenetic minerals, particularly in its lower part, indicate that the sediment generating L. 12 was affected by pedogenetic processes; thus it evolved outside the cavity. As indicated by $\mathrm{CaCO}_{3}$ and organic carbon content, the soil-forming processes affected the lower part of the deposit more strongly than its upper part (particularly L.12b, but also L12c). The same chemical soil properties suggest a perceptible weakening of the impact of the pedogenetic processes in the upper part of the deposit (L.12a) as well as in L.11.

Subsequently the heterometric soil sediments were transported into the cavity. As explored earlier (Dubois and Stehlin, 1932/1933) the karstic chimneys of the cavity are completely plugged by metres of limestones; therefore the coarse deposit must have been transferred by horizontal transport. Although some fine material might have been deposited by water seepage through karstic fissures of the cavity roof, the morphology of the deposits (intermixed coarse and granular fine fraction, absence of stratification, homogeneous presence of granular, humiferous fine material) indicate deposition by mass movement, in which the fine and 
coarse materials were transported together. In addition, the distinct layering (L.12c to L.12a,) observed both in 2016 and by former studies (Dubois and Stehlin, 1932/1933; Rentzel, 1990) and the presence of a considerable amount of organic matter clearly indicate that deposition of this sediment occurred in several phases. Solifluction processes and soil creep triggered by repeated intensive freezing conditions and the presence of frozen ground (Bertran et al., 1997) can best explain the morphology of the L.12 and its characteristics, such as (i) the heterometric nature of the deposit, (ii) rounded allochthonous gravels associated with more angular, more or less polished local limestone fragments, and (iii) homogeneous distribution of the organic material throughout a $180 \mathrm{~cm}$ thickness. The L.11, occurring only at the entrance of the cavity, might be a solifluction deposit.

To conclude, L.12 and L.11 are the result of combined deposition of heterometric soil sediments stemming from the cavity entrance and of fragments resulting from the physical breakdown of the limestone hosting the cavity. They record multiple cycles of alternation of soil formation processes and frost-related sedimentation that occurred after ca. $67 \mathrm{ka}$ and before ca. $36 \mathrm{ka}$. This period corresponds to the time span of Gossau PAZ2 to Gossau PAZ5 (Preusser et al., 2003), i.e. roughly to the major part of MIS 3 (Fig. 10). For this period, environmental archives support an ice-free but fluctuating cold and milder climate with changing ecosystems alternating among coniferous forest, steppe, and tundra (Preusser et al., 2003; Drescher-Schneider et al., 2007; Becker et al., 2013; Bichet et al., 2016).

The sediment and soil characteristics of L.12 and L.11 are in good agreement with these environmental trends, showing regular organic matter accumulation and some decarbonatation outside the cavity during milder climatic conditions. This was followed by destabilisation of vegetation cover and of soils and physical breakdown of the ceiling during cooler phases. The reworking of these pedosediments towards the cavity suggests repeated periods of frozen subsoils enabling soil creep processes. The numerous faunal remains found all over this layer (Dubois and Stehlin, 1932/1933) also confirm the hypothesis of cyclic soil formation processes and recurrent deposition over a long time span. Whereas the large mammal remains indicate a wide variety of ecosystems (Table 2), the rodent remains are heliophile and forest species (Table 3). A brief pollen study (Bezat, 1990) revealing the dominance of the arboreal and shrub pollen in one sample of L.12 further confirms at least one phase of interstadial climatic conditions.

Based on their stratigraphic position, the soils generating L. $12 \mathrm{c}$ and L. $12 \mathrm{~b}$, characterised by marked pedogenetic transformations, can be possibly correlated to the phases Gossau PZ2 and PZ4, respectively. Their transport in the cavity could be related to the colder conditions that are known as Gossau PZ3 and PZ5 (Fig. 10). The upper part of L.12 (L12a) and L.11 show less distinct pedogenetic processes (significant organic matter decrease, the noteworthy $\mathrm{CaCO}_{3}$ and coarse fraction augmentation). This can be best explained by the more and more important cooling that occurred during the passage towards the LGM. The soil formation and sedimentation trends described here present strong similarities with those described for the Ferrassie rock shelter record in SW France (Bertran et al., 2008) and this highlights the potential of terrestrial sediments to document gradual environmental changes.

\subsection{Glacier processes during the Last Glacial Maximum}

In the sedimentary record of Cotencher cave the advent of the LGM is marked by the gully incision towards the entrance of the cavity that erodes the upper part of the porous and heterometric sediments of L.12 and deposits the coarse sediment of L.10. Torrential flow at this landscape position (ca. $140 \mathrm{~m}$ above the valley bottom) can only be explained by the presence of a glacier that was accompanied by meltwater at its margin and frozen ground in the surroundings. The incision process was followed by the formation of a pond with fine material sedimentation (L.9) and this is a further indication of frozen grounds. This slow deposition was followed by more or less dynamic overland or concentrated water flow (L.8). All these deposits underwent severe and repeated freeze-thaw processes as indicated by the cryoturbation features. This cluster of sedimentary and morphological evidence reveals severe climatic deterioration, the quasi absence of vegetation, and the presence of a glacier in the surroundings. Petrographic data (Table 6, Fig. 9) suggest that a local glacier occupied parts of the Areuse canyon. Our data are in good agreement with Pasquier et al. (2013), who documented till deposits composed of gravels of local origin underlying fine sediments and tills of alpine origin. The timing of these events triggered by the local glacier is about $36.6 \pm 3.8 \mathrm{ka}$ (COT-3) and gives a novel and valuable chronological indication for an early onset of a glacial environment in the Jura Mountains, more precisely in the Travers Valley. This date is several thousand years older than those known in the lowlands of the northern Alpine foreland. At Finsterhennen (ca. $40 \mathrm{~km}$ from the site), the northern lobe of the Rhone glacier started to deposit proglacial sediments at about $30 \mathrm{ka}$ (Preusser et al., 2007). Similarly, higher up in the Jura Mountains, the landscape was also not yet covered by ice, as is indicated by dates provided by various faunal records. Indeed, at the Baume de Longaigue (820-920 m), situated higher up in the studied valley, an ibex bone has been accelerator mass spectrometry (AMS) dated to $34840 \pm 340 \mathrm{BP}$ (Leesch et al., 2013) and an open landscape suggesting faunal assemblage found in a cave at La Chaux-de-Fond (1020 m, Fig. 1) has been AMS dated to $32590 \pm 630 \mathrm{BP}$ (Oppliger, 2010, in Leesch et al., 2013).

This apparent relatively early formation of a local glacier in the Areuse canyon was possibly due to its particular geomorphological, climatic, and microclimatic conditions in a severely cooling regional climate. As highlighted by Buon- 
cristiani and Campy (2011), the morphology of some of the valleys in the Jura Mountains, the average cool conditions, and the exposure to northeast winds created sufficiently arctic conditions for local glacier development. The importance of the local geomorphological factors is still evident in the present-day climatic conditions. Indeed, higher up in the valley the sunshine-sheltered "Creux-du-Van" setting is a place where a ca. $20 \mathrm{~m}$ thick permafrost still exists in the scree situated under the mountain cliff at about $1200 \mathrm{~m}$ (Pancza, 1988/1989; Delaloy and Reynard, 2001). This location could have been the place of birth of the local glacier that invaded the valley downstream and caused sediment deposition at the level of the studied site. Furthermore, the Jura Mountains are a geomorphological barrier for the Atlantic humid air masses, and the high precipitation associated with low evapotranspiration was probably an additional factors triggering early local glacier development.

The first phase of erosion-sedimentation processes revealing the existence and closeness of a local glacier was followed by the deposition of L.7. The transition from the underlying pond environment is gradual and reveals a glaciolacustrine setting. The analytical data further support an environment with no or scarce vegetation cover. The stratigraphic position and the dating performed indicate that this sedimentation took place between ca. $36.6 \pm 3.8$ and $30.0 \pm 3.0 \mathrm{ka}$ (COT3, COT4), thus just prior to the LGM and in continuity of sedimentary processes discussed for L.10 to L.8. The deep freeze-thaw processes were probably very active and the cryoturbation processes recorded by the underlying L.8 and L.9 are probably related at least partially to this period. The deposition of L.7 corresponds to the expansion of glaciers of the LGM in both the Jura and the northern Alpine foreland (Preusser, 2004; Preusser et al., 2011). However the continuous fine sediment accumulation indicates that the surroundings of the cave were not yet completely covered by ice, but torrential water flow associated with its margins was replaced by calmer overland and lateral water flow processes.

A break in the fine sediment input is recorded by the L.6. This period, which lasted from about $30.0 \pm 3.0$ to $26.5 \pm 2.8 \mathrm{ka}$ (COT4, COT5) was characterised inside the cave by intensive (cryo)shattering of the cave roof and the formation of ice wedge in the already existing sediments. The sedimentary hiatus unravelled here can be interpreted as an indication that the cavity entrance was plugged by ice and/or sediment.

The next sedimentary phase materialised by L.5 indicates renewed overland water flow possibly accompanied by aeolian sediment input in an environment with absent or little vegetation cover. The accumulation of this sediment was also accompanied by frost shattering of the limestones hosting the cavity and deep freeze-thaw processes. These processes started at about $26.5 \pm 2.8 \mathrm{ka}$ (COT5) but we do not have data to further constrain the time span of this sediment accumulation. The onset of sedimentary processes and the absence of vegetation cover might be interpreted as (i) evidences of deglaciation at the level of the cave or (ii) the sedimentary fingerprint of the complex processes associated with the passage between the local glacier and the alpine glacier. This date is consistent with existing chronological evidences that expect the start of deglaciation at the maximum extent of the Rhone glacier not later than $24 \pm 2 \mathrm{ka}$ (Ivy-Ochs, 2015). First vegetation re-colonisation in the lowlands around Neuchâtel Lake is estimated at around $19 \mathrm{ka}$ (Thew et al., 2009).

The sediments of L.10, L.9, L.7, L.8, L.6, and L.5 thus show some important phases of the sedimentary dynamics that occurred in the studied region and at the level of the site during the LGM: (i) presence of a local glacier at the altitudes close to Cotencher cave at about $36.6 \pm 3.8$ ka triggering erosion processes and sediment deposition, (ii) followed by the growth of the ice body, filling up the valley at the level of the cavity entrance accompanied by a sediment hiatus that lasted from ca. $30.6 \pm 3.0$ to $26.5 \pm 2.8 \mathrm{ka}$ and (iii) fine material sedimentation in an environment with no vegetation cover post $26.5 \pm 2.8 \mathrm{ka}$. A succession of a local till overlaid by glaciolacustrine sediments followed by till of alpine origin covered by glaciolacustrine sediments is documented in cores and outcrops situated upstream of the site (Pasquier et al., 2013; Mojon et al., 2015). The sedimentary evidences and chronological data provided here complete this geological record and bring novel elements into the knowledge and timing of the regional glaciation history.

\subsection{Dynamics of human activities}

The new chronological and environmental information combined with available archaeological data permit us to readdress the question of the nature, location, and timing of human presence at Cotencher cave and its surroundings. This subject concerns three aspects: the nature of this activity, its location, and its timing.

In the review of Mousterian occupation of the Jura Mountains, Detrey (2013) concludes that the Travers Valley was used not only as passage for Palaeolithic people, but this internal part of the mountain chain was also a place of exploitation of lithic resources and rich in potential prey. The techno-economic analyses of the lithic assemblage of Cotencher cave have been interpreted as indicating temporary dwelling under the rock shelter, with a mixed economic vocation (production and consumption of blanks) that was possibly frequented on several occasions (Bernard-Guelle, 2004). Our study confirms that the tools found in earlier excavations can be characterised as Charentian Mousterian of oriental Quina type. Moreover, the study of the material collected in 2016 unravels the presence of numerous chips witnessing debitage (or flaking) operations, the manufacturing and sharpening of tools at the level of the site. The faunal remains analysed so far could not reveal any unequivocal trace of anthropic action; thus the bone assemblage does not permit further discussion of the nature of human activity. 
The location of the human activity remains difficult to assess. Dubois and Stehlin (1932/1933, p. 189) mentioned charcoal and burned stones without lithic tools at the bottom of the cave in the lower part of the brown layer. They interpret these finds as the remains of two fireplaces and if this assumption was correct it would imply an occupation pre-dating $67 \mathrm{ka}$. The lithic artefacts are present in the deposits situated under L.15 (brown layer) and in L.12 (gravelly layer). The brown layer contains only a minor amount of this find (Table 1) and according to the available data it is mostly situated in the upper part of it. This imprecise information does not permit us to assert the timing of the human activity materialised by the tools found in this stratigraphic unit. Indeed several hypotheses can be formulated, but none of them can be eliminated: (i) they could have been reworked from outside during the deposition of the brown layer or of the L.15 and L.16, and thus might be older than $67 \mathrm{ka}$; (ii) they might be the results of in situ activity inside the cavity during or by the end of the accumulation of this layer but before the deposition of L.14 and L.13, thus once more reflecting human activity older than $67 \mathrm{ka}$; (iii) they could be stemming from the overlying L. 12 due to bioturbation or cryoturbation processes and in this case they would be the reworked traces of the seasonal anthropic activity, which took place at the level of the rock shelter between ca. 67 and $36 \mathrm{ka}$. As for the L.12, although burned stones and bones were regularly observed in this layer, so far there are no elements clearly supporting in situ human activity inside the cavity. In absence of these features, we can only formulate that the lithic tools were used at the external rock shelter part of the site and they were deposited as part of L.12 during multiple processes of soil creep that occurred over a time span of some 10000 years, i.e. after the deposition of the sediment source of L.12 at around $72 \mathrm{ka}$ and before $36 \mathrm{ka}$. The study of vestiges found in 2017 might give arguments to complete this interpretation.

Based on the study of the lithic industry, Bernard-Guelle (2004) concludes that the lithic artefacts that are spread all over the two find layers (red and gravelly layer) are possibly related to the reworking of one single archaeological level, located initially at the entrance of the cavity. The sedimentological study performed here contests this interpretation. First of all, these two layers have considerably different sedimentological and pedological characteristics and they have been deposited during distinct and rather distant time frames. In addition, sediments supporting the development of a glacier, reaching more or less the level of the cavity, separate the two layers that contain the lithic and faunal finds. As developed here above, the brown layer has been deposited and evolved inside the cavity after the last interglacial and before ca. $67 \mathrm{ka}$. The sedimentation of L.12 in the cavity post-dates the marked cooling at about $67 \mathrm{ka}$ and it occurred during multiple phases up to about $36 \mathrm{ka}$. The soil characteristics of this reworked sediment suggest several distinct phases of pedogenetic evolution outside the cavity. As a consequence the artefacts reworked inside the cavity through the successive mass movements are, at least partially, related to recurrent human activity on the soil surface at the entrance of the cavity, over a time span of several thousands of years.

The climatic fluctuations unravelled here also permit us to modestly complete the already existing considerations concerning the relationship between the succeeding climates and distribution of the Palaeolithic sites in the studied region. The Mousterian sites, although not numerous, are present on both sides of the Jura Mountains (Le Tensorer, 1998; Tillet, 2000, 2001; Detrey, 2013). The marked dissymmetry in the frequency of sites between the northwester slopes (more abundant) and southeaster flanks (scarce) has been explained (i) by the erosion processes more active on the Helvetic side due to the glacier passage during the LGM and (ii) by the more abundant silex outcrop on the French side. Moreover, Detrey (2013) highlights the fact that among the sites post-dating MIS 5, there is a hiatus corresponding to MIS 4 and the early part of MIS 3 . The Cotencher data acquired here might at least partially explain this fact. As discussed above, around $67 \mathrm{ka}$ a local glacier developed at the level of the cave, but likely also in some other parts of the Jura Mountains (Bichet et al., 2016). The erosion triggered by this glacier passage, as well as the hostile landscape, nonsuitable for anthropic activity, could be the cause of this hiatus. As for the early Upper Palaeolithic sites (Aurignacian, Gravettian), they are completely absent in the Jura Mountains (Leesch et al., 2013) and in Switzerland (Cattin et al., 2009; Leesch and Bullinger, 2013). In addition to the erosion processes induced by the glaciers of the LGM, the relatively limited prospection and research programs are thought to be possibly responsible for this lack (ibid). Nevertheless it seems that the Jura Mountains represented a barrier region that the people preferred to avoid during the Upper Palaeolithic in the Jura Mountains (Leesch and Bullinger, 2013). Once more the sedimentary and chronological evidences of the deposits accumulated in Cotencher cave support this fact. The local glacier was active at the level of the cavity as early as ca. $36.1 \pm 3.5 \mathrm{ka}$ (COT3) and a glacio-lacustrine type of sedimentation was active at least up to $26.5 \pm 2.8 \mathrm{ka}$ (COT1). This environmental setting was once more not attractive for the hunter-gatherer populations.

\section{Conclusions}

The interdisciplinary study of the sedimentary fill of Cotencher cave permitted us to unravel and date several significant environmental changes encoded in these deposits. According to this, two periods of glacier development are documented for the Late Pleistocene. Compared to the chronology known for alpine glaciers advancing into the lowlands, a particular early development of a local glacier is apparently revealed for the LGM. These data imply new elements for the understanding of the dynamics of this major climatic change. As for the climatic deterioration of MIS 4, the Cotencher sed- 
iments support a local glacier build-up and these data complete the scarce regional terrestrial record. The new archaeological information clearly reveals manufacturing and sharpening activities of Mousterian tools at the level of the site. Although it is still not possible to delimit the precise location of the various occupations, this study points out two of their characteristics: (i) at least part of them occurred at the entrance rock shelter part of the cavity and (ii) a repeated visiting of the site occurred over a long time span. The integration of the sedimentological and chronological data also permitted us to formulate a hypothesis concerning some of the questions raised about the dynamics of human passage in the studied region. According to our data the particular hostile glacier landscape explains, at least partially, the absence of traces of human activity for both the period of MIS 4-early MIS 3 and the early Late Palaeolithic.

Data availability. Most of the underlying data are included in the paper. Our site is still under study as part of a larger project of the Neuchâtel Archaeological Service. For this reason part of our underlying data are not yet publicly available.

Author contributions. JD carried out the field work (observations, descriptions, sampling) and the selection of samples for analyses; she interpreted the analytical data, drew the graphs, and created the sedimentological tables; she set up the sieving protocol and supervised the sieving; she set up the petrographic analyses protocol and performed petrographic study; she wrote the paper in collaboration with FP, MIC, and FXC. FP carried out the IRSL sampling, processing, and analyses; MIC carried out the field work (digging and sampling), examined and interpreted the lithic collections, and created the table concerning the lithic artefacts; JCC studied and interpreted the bone collection; FXC conceived and coordinated this project; he led and carried out the field work (digging and sampling), handled the various archaeological collections, and created the tables concerning the faunal remains.

Competing interests. The authors declare that they have no conflict of interest.

Acknowledgements. We express our gratitude to Sonia Wüthrich, head of the archaeology section of Neuchâtel canton, Frédéric Cuche, president of the association of "Maison de la Nature Neuchâteloise", and Marc-Antoine Kaeser, director of Laténium, Parc et musée d'archéologie de Neuchâtel, for the opportunity and support to perform this research.

We sincerely acknowledge our colleagues of the Office du patrimoine et de l'archéologie de Neuchâtel for their help: Frédéric Brenet contributed substantially to the excavation work, performed the sieving, and drew the figures; Marc Juillard, Julien Spielmann, and Philippe Zuppinger helped us with the photographic documentation, the topographic measures, and the illustrations. We are greatly indebted to Vincent Bichet, Michel Campy
(Université de Franche-Comté), Stéphane Gogniat (Hydrogeos), Thierry Malvésy, and Bernard Claude (Muséum d'histoire naturelle de Neuchâtel) for the helpful and stimulating discussions. Philippe Rentzel (IPNA, Basel), Stéphanie Wirth (CHYN, Université de Neuchâtel), and François Pasquier kindly helped to find data and reference material. The pedological analyses were performed in the LAS (EOST, Université de Strasbourg) and we are grateful to Martine Trautmann for the efficient handling of our samples.

Sébastien Bernard-Guelle, the anonymous reviewer, and Christopher Lüthgens are sincerely acknowledged for their constructive and helpful comments and suggestions.

This study is part of a regional landscape and natural coordination "Cotencher project", coordinated by François-Xavier Chauvière. We would like to thank Loterie romande, Fondation Ernest Dubois, Fondation Göhner, Fondation Sophie et Karl Binding, Fondation du Casino de Neuchâtel, La Migros Neuchâtel-Fribourg, ECOFORUM, and Société d'histoire et d'archéologie du canton de Neuchâtel for the financial support. We express our appreciation of all the participants and partner institutions for their collaboration.

\section{References}

Adatte, T., Rentzel, P., and Kübler, B.: Etude minéralogique et sédimentologique du remplissage de la grotte de Cotencher (Jura neuchâtelois, Suisse), Eclogae Geol. Helv., 84, 671-688, 1991.

Angelucci, D. E., Anesin, D., Susini, D., Villaverde, V., Zapata, J., and Zilhão, J.: Formation processes at a high resolution Middle Paleolithic site: Cueva Antón (Murcia, Spain), Quaternary Int., 315, 24-41, 2013.

Auclair, M., Lamothe, M., and Huot, S.: Measurement of anomalous fading for feldspar IRSL using SAR, Radiat. Meas., 37, 487-492, 2003.

Bay, R.: Der menschliche Oberkiefer aus der Grotte de Cotencher (Rochefort, Neuchâtel, Suisse), Archives suisses d'anthropologie générale, 451, 57-101, 1981.

Becker, D., Oppliger, J., Thew, N., Scherler, L., Aubry, D., and Braillard, L.: Climat et écologie en Ajoie durant la second partie du Pleniglaciaire moyen weichsélien: apport des remplissage des dolines de Courtedoux-Vâ Tche Tchâ (Jura, CH), in: Le peuplement de l'Arc jurassien de la Préhistoire au Moyen Âge. Actes des deuxièmes journées archéologiques frontalières de l'Arc jurassien, Delle (F) -Boncourt (CH), edited by: Richard, A., Schifferdeccker, F., Mazimann J.-P., and Bélet-Gonda, C., 16-18 November 2007, Presses Universitaire de Franche-Compté, Besançon, 13-23, 2013.

Bernard-Guelle, S.: Un site moustérien dans le Jura suisse: la grotte de Cotencher (Rochefort, Neuchâtel) revisitée, Bulletin de la Société préhistorique Française, 101, 741-769, 2004.

Bertran, P., Hétu, B., Texier, J.P. and Steijn, H.: Fabric characteristics of subaerial slope deposits, Sedimentology, 44, 1-16, 1997.

Bertran, P., Caner, L., Langohr, R., Lemée, L., and d'Errico, F.: Continental palaeoenvironments during MIS 2 and 3 in southwestern France: the La Ferrassie rockshelter record, Quaternary Sci. Rev., 27, 2048-2063, 2008.

Bezat, E.: Analyse pollinique, Cotencher Sondage 1988 - P1, in: Neue quatärgeologische Untersuchungen an den Höhlensediementen von Cotencher (Kt. NE), edited by: Renztel, P., 
Labor für Ur- und Frühgeschichte der Universität Basel, 76-81, 1990.

Bichet, V., Buoncristiani, J.-F., and Ravier, É.: Identification de sédiments du stade isotopique 3 (OIS-3) dans les formations proglaciaires du haut Jura, in: De la reconstitution des paysages à l'histoire des sociétés, edited by: Barral, P. M. M. and Ravier E., 10000 d'archives sédimentaires en zones humides, Infolio, Gollion, Switzerland, 19-27, 2016.

Bini, A., Buoncristiani, J. F., Coutterand, S., Ellwanger, D., Felber, M., Florineth, D., Graf, H. R., Keller, O., Kelly, M., Schlüchter, C., and Schoeneich, P.: Die Schweiz während des letzteiszeitlichen Maximum (LGM) 1:500000, Carte et notice, Bundesamt für Landestopografie Swisstopo, Wabern, 2009.

Blant, M. and Deriaz, P.: Le gisement paléontologique du Pléistocène supérieur de la grotte du Balai (Saint-Croix, Vaud), Stalactite supplément, 16, 155-158, 2007.

Boschian, G., Gerometta, K., Ellwood, B. B., and Karavanić, I.: Late Neandertals in Dalmatia: Site formation processes, chronology, climate change and human activity at Mujina Pećina, Croatia, Quaternary Int., 450, 12-35, 2017.

Braillard, L., Guélat, M., and Rentzel, P.: Effects of bears on rockshelter sediments at Tanay Sur-les-Creux, southwestern Switzerland, Geoarchaeology, 19, 343-367, 2004.

Bullock, P., Fedoroff, N., Jongerius, A., Stoops, G., and Tursina, T.: Handbook for soil thin section description, Waine Research, Wolverhampton, 1985.

Buoncristiani, J.-F. and Campy, M.: Quaternary Glaciations in the French Alps and Jura, in: Ehlers, J., Gibbard, P. L., and Hughes, P. D., Developments in Quaternary Science. Quaternary glaciations - extent and chronology, Elsevier, Amsterdam, the Netherlands, 117-126, 2011.

Buylaert, J. P., Murray, A. S., Thomsen, K. J., and Jain, M.: Testing the potential of an elevated temperature IRSL signal from K-feldspar, Radiat. Meas., 44, 560-565, 2009.

Buylaert, J. P., Jain, M., Murray, A. S., Thomsen, K. J., Thiel, C., and Sohbati, R.: A robust feldspar luminescence dating method for Middle and Late Pleistocene sediments, Boreas, 41, 435-451, 2012.

Campy, M.: Palaeogeographical relationship between Alpine and Jura glaciers during the two last Pleistocene glaciation, Palaeogeogr. Palaeocl., 93, 1-12, 1992.

Castel, J.-C.: The faunal remains at Roc-de-Marsal and game exploitation in the Mousterian of Southwest France, Variability in Human Hunting Behavior during Oxygen Isotope Stages 4/3: Implications for Understanding Modern Human Origins. ICAZ Paris 2010, S5, 4, 2010.

Castel, J.-C., Luret, M., and Chaix, L.: Hommes et bêtes au Moustérien, in: La Haute-Savoie durant la Préhistoire, edited by: Serralongue, J., Culture 74/08, Haute-Savoie, 60-64, 2012.

Castel, J.-C., Discamps, E., Soulier, M.-C., Sandgathe, D., Dibble, H. L., McPherron, S. J. P., Goldberg, P., and Turq, A.: Neandertal subsistence strategies during the Quina Mousterian at Roc de Marsal (France), Quaternary Int., 433, 140-156, 2017.

Cattin, M.-I., Affolter, J., and Thew, N.: Provenance de diverses matières premières: un indice pour définir circulations et territoires au Magdalénien supérieur en Suisse, in: Le concept de territoires dans le Paléolithique supérieur européen, edited by: Djindjian F., Kozlowski, J., and Bicho, N., actes 15e Congrès
UISPP, Lisbonne, September 2006, Oxford BAR S1938, Lisbonne, 157-165, 2009.

Chauvière, F.-X., Cattin, M.-I., Deák, J., and Brenet, F.: Le petit racloir moustérien: un retour à la grotte paléolithique de Cotencher (Rochefort, NE), Nike-Bulletin, 1, 32-35, 2018a.

Chauvière, F.-X., Deák, J., Cattin, M.-I., Brenet, F., Juillard, M., Castel, J.-C., Oppliger, J., and Preusser, F.: La grotte de Cotencher: une (pré)histoire humaine et naturelle. Archéologie Suisse: Neuchâtel les nouvelles voies de 1'archéologie, Archéoloogie Suisse, 41, 16-20, 80, 2018b.

Chauvière, F.-X., Deák, J., Cattin, M.-I., Brenet, F., Juillard, M., Castel, J.-C., Oppliger, J., and Preusser, F.: Die Höhle von Cotencher: eine menschliche und natürliche (Vor-)Geschichte, Archäologie Schweiz: Neuenbourg, neue Wege der Archäologie, Archäologie Schweiz, 41, 16-20, 80, 2018c.

Crotti, P.: Le peuplement paléolithique et mésolithique de la Suisse: la question de l'utilisation des étages montagnards dans les Alpes, Geogr. Helv., 63, 167-175, https://doi.org/10.5194/gh-63167-2008, 2008

Cupillard, C., Magny, M., Bocherens, H., Bridault, A., Bégeot, C., Bichet, V., Bossuet, G., Drucker, D. G., Gauthier, E., Jouannic, G., Millet, L., Richard, H., Rius, D., Ruffaldi, P., and WalterSimonnet, A.-V.: Changes in ecosystems, climate and societies in the Jura Mountains between 40 and $8 \mathrm{ka}$ cal BP, Quaternary Int., 378, 40-72, 2015.

Deák, J.: Geoarchäologie oder das „Gedächtnis der Böden“, Archäologie Schweiz: Neuenbourg, neue Wege der Archäologie, Archéologie Suisse, 41, 36-40, 80, 2018a.

Deák, J.: La géoarchéologie ou la mémoire des „,sols“, Archéologie Suisse: Neuchâtel les nouvelles voies de 1'archéologie, AS, 41, 36-40, 80, 2018b.

Delaloy, R. and Reynard, E.: Les éboulis gelés du Creux du Van (Chaîne du Jura, Suisse), Environnements Périglaciaire, 8, 118129, 2001.

De Rougemont, D.: Monnaies trouvées lors des fouilles de 1917 à Cotencher NE, Gazette numismatique suisse, 28-32, 100-104, 1982.

Desor, E.: Théorie de l'époque glaciaire, Congrès International d'Anthrolpologie et d'archéologie préhistorique, Compte rendu de la 2eme session, Paris, 1867, Paris C. Reinwald, Libraireéditeur, 275-276, 1868.

Desor, E.: Essai d'une classification des cavernes du Jura, Bulletin de la Société des Sciences Naturelles de Neuchâtel, 9, 69-87, 1872.

Detrey, J.: Nouvelles données sur le Paléolithique moyen dans le canton du Jura (Suisse), Revue Archéologique de l'Est, 59, 7 45, 2010.

Detrey, J.: Présence moustérienne dans l'arc jurassien: un état de la question, in: Deuxièmes journées archéologiques frontalières de l'Arc jurassien. Actes, Le peuplement de l'Arc jurassien de la Préhistoire au Moyen Âge. Besançon, edited by: Richard, A., Schifferdeccker, F., Mazimann J.-P., and Bélet-Gonda, C., Presses Universitaires de Franche-Comté et Porrentruy, Office de la culture et Société jurassienne d'émulation, Delle, France - Boncourt, Switzerland, 16-18 November 2007, 41-70, 2013.

Drescher-Schneider, R., Jacquat, C., and Schoch, W.: Palaeobotanical investigations at the mammoth site of Niederweningen (Kanton Zürich), Switzerland, Quaternary Int., 164-165, 113-129, 2007. 
Dubois, A.: Note sur les fouilles exécutées en 1916 dans la grotte de Cotencher, Le Rameau de sapin, IIème série, 14-15, 1917.

Dubois, A.: Les fouilles de la grotte de Cotencher, Le véritable messager boiteux de Neuchâtel, 72-74, 1918.

Dubois, A.: Les Fouilles de la Grotte de Cotencher, Actes de la Société Helvétique des Sciences, 101, 99-122, 1920.

Dubois, A. and Stehlin, H. G.: La grotte de Cotencher: station moustérienne, Emil Birkhaeuser\&Cie, Bâle, 1932/1933.

Duller, G. A. T.: Single-grain optical dating of Quaternary sediments: why aliquot size matters in luminescence dating, Boreas, 37, 589-612, 2008.

Egloff, M.: Musée cantonal d'archéologie, Ville de Neuchâtel, Bibliothèques et musées, 1975, 91-95, 1976.

Egloff, M.: Des premiers chasseurs au début du christianisme Histoire du Pays de Neuchâtel, 1. De la préhistoire au Moyen-Age, Attinger, Neuchâtel, 9-160, 1989.

Feathers, J. K.: Luminescence dating and modern human origins, Evol. Anthropol.-Issues, News, and Reviews, 5, 25-36, 1996.

Furrer, H., Graf, H. R., and Mäder, A.: The mammoth site of Niederweningen, Switzerland, Quaternary Int., 164-165, 85-97, 2007.

Gaar, D. and Preusser, F.: Luminescence dating of mammoth remains from northern Switzerland, Quaternary Geochronol., 10, 257-263, 2012.

Gaar, D., Lowick, S. E., and Preusser, F.: Performance of different luminescence approaches for the dating of known-age glaciofluvial deposits from northern Switzerland, Geochronometria, 41, 65-80, 2014.

Galbraith, R. F., Roberts, R. G., Laslett, G. M., Yoshida, H., and Olley, J. M.: Optical dating of single and multiple grains of quartz from Jinmium rock shelter, Northern Australia: part I, experimental design and statistical models, Archaeometry, 41, 339364, 1999.

Gigon, R.: Inventaire Spéléologique de la Suisse, tome 1: Canton de Neuchâtel, Commission de Spéléologie de la Société helvétique des Sciences Naturelles, Neuchâtel, 1976.

Goldberg, P. and Macphail, R. I.: Caves and rockshelters, in: Practical and theoretical geoarchaeology, edited by: Goldberg, P. and Macphail, R., Blackwell Publishing, Malden, 169-187, 2006.

Goldberg, P., Schiegl, S., Meligne, K., Dayton, C., and Conard, N. J.: Micromorphology and site formation at Hohle Fels Cave, Swabian Jura, Germany, Eiszeitalter und Gegenwart, 53, 1-25, 2003.

Graf, A. A., Strasky, S., Ivy-Ochs, S., Akçar, N., Kubik, P. W., Burkhard, M., and Schluchter, C.: First results of cosmogenic dated pre-Last Glaciation erratics from the Montoz area, Jura Mountains, Switzerland, Quaternary Int., 164-165, 43-52, 2007.

Guérin, G., Valladas, H., Joron, J.-L., Mercier, N., Reyss, J.-L., and Zaidner, Y.: Apports de la datation par la luminescence des sites du Proche-Orient et résultats préliminaires du site de Nesher Ramla (Israël), L'Anthropologie, 121, 35-45, 2017.

Hajdas, I.: Radiocarbon dating and its applications in Quaternary studies, E\&G Quaternary Sci. J., 57, 2-24, https://doi.org/10.3285/eg.57.1-2.1, 2008.

Hajdas, I., Bonani, G., Furrer, H., Mäder, A., and Schoch, W.: Radiocarbon chronology of the mammoth site at Niederweningen, Switzerland: Results from dating bones, teeth, wood, and peat, Quaternary Int., 164-165, 98-105, 2007.

Heiri, O., Koinig, K. A., Spötl, C., Barrett, S., Brauer, A., DrescherSchneider, R., Gaar, D., Ivy-Ochs, S., Kerschner, H., Luetscher,
M., Moran, A., Nicolussi, K., Preusser, F., Schmidt, R., Schoeneich, P., Schwörer, C., Sprafke, T., Terhorst, B., and Tinner, W. Palaeoclimate records $60-8 \mathrm{ka}$ in the Austrian and Swiss Alps and their forelands, Quaternary Sci. Rev., 106, 186-205, 2014.

Higham, T.: European Middle and Upper Palaeolithic radiocarbon dates are often older than they look: problems with previous dates and some remedies, Antiquity, 85, 235-249, 2015.

Huntley, D. J. and Baril, M. R.: The K content of the K-feldspars being measured in optical dating or in thermoluminescence dating, Ancient TL, 15, 11-13, 1997.

Huntley, D. J. and Lamothe, M.: Ubiquity of anomalous fading in $\mathrm{K}$-feldspars and the measurement and correction for it in optical dating, Can. J. Earth Sci., 38, 1093-1106, 2001.

Ivy-Ochs, S.: Glacier variations in the European Alps at the end of the last glaciation, Cuadernos de investigación geográfica, 41, 295-315, 2015.

Ivy-Ochs, S., Kerschner, H., Reuther, A., Preusser, F., Heine, K., Maisch, M., Kubik, P. W., and Schlüchter, C.: Chronology of the last glacial cycle in the European Alps, J. Quaternary Sci., 23, 559-573, 2008.

Jacobs, Z. and Roberts, R. G.: Advances in optically stimulated luminescence dating of individual grains of quartz from archeological deposits, Evol. Anthropol.-Issues, News, and Reviews, 16, 210-223, 2008.

Lee, M. K., Lee, Y. I., Lim, H. S., Lee, J. I., Choi, J. H., and Yoon, H. I.: Comparison of radiocarbon and OSL dating methods for a Late Quaternary sediment core from Lake Ulaan, Mongolia, J. Paleolimnol., 45, 127-135, 2011.

Leesch, D. and Bullinger, J.: Le Plateau suisse et le massif du Jura pendant le Paléolithique supérieure ancien: paléoenvironnment et indices d'occupation humaine, Mémoire LVI de la Société préhistorique française, Le Paléolithique supérieure ancien de l'Europe du Nord-Ouest, 385-394, 2013.

Leesch, D., Bullinger, J., and Cupillard, C.: Le peuplement de l'arc jurassien au Paléolithique supérieur, Le peuplemenr de l'Arc jurassien de la Préhistoire au Moyen Âge, Actes des deuxièmes journées archéologiques frontalières de l'Arc jurassien, Delle, France - Boncourt, Switzerland, 16-18 November 2007, Presses universitaire de Franche-Compté., Annales Littéraires de l'Université de Franche-Compté, série Environnement, sociétés et archéologie 17, Cahier d'archéologie jurassienne, 21, 71-84, 2013.

Le Tensorer, J.-M.: Méthodologie et chronologie La Suisse du Paléolithique à l'aube du Moyen-Age. De l'Homme de Néandertal à Charlemagne, 1. Paléolithique et Mésolithique, Société suisse de préhistoire et d'archéologie, Bâle, 15-38, 1993.

Le Tensorer, J.-M.: Le Paléolitique en Suisse, Jérôme Millon, Grenoble, 1998.

Lisiecki, L. E. and Raymo, M. E.: A Pliocene-Pleistocene stack of 57 globally distributed benthic $\delta^{18} \mathrm{O}$ records, Paleoceanography, 20, 1-17, 2005.

Lowick, S. E., Trauerstein, M., and Preusser, F.: Testing the application of post IR-IRSL dating to fine grain waterlain sediments, Quaternary Geochronol., 8, 33-40, 2012.

Lowick, S. E., Buechi, M. W., Gaar, D., Graf, H. R., and Preusser, F.: Luminescence dating of Middle Pleistocene proglacial deposits from northern Switzerland: methodological aspects and stratigraphical conclusions, Boreas, 44, 459-482, 2015. 
Mathieu, C. and Pieltain, F.: Analyse chimique des sols, Méthodes choisies, Edition Tec and Doc Paris, 2003.

Méia, J. and Becker, F.: Notice explicative et feuille 1164, Neuchâtel, Commission géologique suisse, 1976.

Météosuisse: Evapotranspiration nach Primault. Neuchâtel, 485 m. 1996-2005, Météosuisse, Geneve, Switzerland, 2005.

Météosuisse: Normes climatologique La Brévine (1961-1990), Chaumon (1961-1990), Neuchâtel (1961-1990), La Chaux-de Fonds (1901-1980), Météosuisse, Genève, Switzerland, 2016.

Miéville, H.: Cotencher. Dictionnaire historique de la Suisse (DHS), available at: http://www.hls-dhs-dss.ch/textes/f/F12556.php (last access: 1 December 2018), 2005.

Mojon, P.-O., Pasquier, F., and Emery-Barbier, A.: Micropaléontologie des dépôts lacustres Tardiglaciaires à Holocènes du Val-de-Travers et de la Vallée des ponts (Jura Suisse NordOccidental), Bulletin de la Société Neuchâteloise des Sciences Naturelles, 135, 51-77, 2015.

Moll, H. F.: Rochefort NE. Grotte de Cotencher, Annuaire de la Société Suisse de Préhistoire et d'Archéologie, 56, 177, 1971.

Moll, H. F.: Die Paläolitische Station von Cotencher (Rochefort NE), Kolloquium: Der fossile Mensch im schweizerischen Palaolithicum, Verhandlungen der Schweizerischen Naturforschenden Gesellschaft, Sektion Anthropologie, 6, 48-49, 1974.

Moll, H. F.: Découverte d'un maxillaire supérieur humain à la grotte de Cotencher (commune de Rochefort, canton de Neuchâtel, Suisse), Bulletin de la Société d'Etudes et de Recherches Préhistoriques des Eyzies, 26, 1-15, 1977.

Munsell Color: Munsell soil color charts, 1994, New Windsor, 1994.

Olley, J. M., Roberts, R. G., and Murray, A. S.: Disequilibria in the uranium decay series in sedimentary deposits at Allen's cave, nullarbor plain, Australia: Implications for dose rate determinations, Radiat. Meas., 27, 433-443, 1997.

Otz, H.-L.: Communication à la séance du 4 avril 1867, Bulletin de la société neuchâteloise des sciences naturelles, 7, 534-536, 1867.

Pancza, A.: Un pergélisol actuel dans le Jura Neuchâtelois, Bulletin de la Société neuchâteloise de géographie, 32-33, 129-140, 1988/1989.

Pasquier, F., Burkhard, M., Mojon, P.-O., and Gogniat, S.: Feuille 1163 Travers-Atlas géol. Suisse $1: 25000$, Notice expl. 162, Office fédérale de topographie, Wabern, Switzerland, 2013.

Prescott, J. R. and Hutton, J. T.: Cosmic ray contributions to dose rates for luminescence and ESR dating: Large depths and longterm time variations, Radiat. Meas., 23, 497-500, 1994.

Preusser, F.: Luminescence dating of fluvial sediments and overbank deposits from Gossau, Switzerland: fine grain dating, Quaternary Sci. Rev., 18, 217-222, 1999.

Preusser, F.: Towards a chronology of the Late Pleistocene in the northern Alpine Foreland, Boreas, 33, 195-210, 2004.

Preusser, F. and Degering, D.: Luminescence dating of the Niederweningen mammoth site, Switzerland, Quaternary Int., 164-165, 106-112, 2007.

Preusser, F. and Kasper, H. U.: Comparison of dose rate determination using high-resolution gamma spectrometry and inductively coupled plasma-mass spectrometry, Ancient TL, 19, 1-24, 2001.
Preusser, F., Geyh, M. A., and Schlüchter, C.: Timing of Late Pleistocene climate change in lowland Switzerland, Quaternary Sci. Rev., 22, 1435-1445, 2003.

Preusser, F., Ramseyer, K., and Schlüchter, C.: Characterisation of low OSL intensity quartz from the New Zealand Alps, Radiat. Meas., 41, 871-877, 2006.

Preusser, F., Blei, A., Graf, H., and Schlüchter, C.: Luminescence dating of Würmian (Weichselian) proglacial sediments from Switzerland: methodological aspects and stratigraphical conclusions, Boreas, 36, 130-142, 2007.

Preusser, F., Graf, H. R., Keller, O., Krayss, E., and Schlüchter, C.: Quaternary glaciation history of northern Switzerland, E\&G Quaternary Sci. J., 60, 21, https://doi.org/10.3285/eg.60.2-3.06, 2011.

Rentzel, P.: Neue quatärgeologische Untersuchungen an den Höhlensediementen von Cotencher (Kt. NE), Diplomarbeit, Labor für Ur- und Frühgeschichte der Universität Basel, 131 pp., 1990.

Rentzel, P.: Lithostratigraphie und Geochronologie der Höhlensediemente von Cotencher (Schweiz, Kt. NE), 9e Congrès national de spéléologie, Société Suisse de Spléléologie et Comission de Spéléologie ASSN, 109-112, 1992.

Richter, D., Richter, A., and Dornich, K.: Lexsyg Smart - a luminescence detection system for dosimetry, material research and dating application, Geochronometria, 42, 202-209, 2015.

Rittenour, T. M.: Luminescence dating of fluvial deposits: applications to geomorphic, palaeoseismic and archaeological research, Boreas, 37, 613-635, 2008.

Roberts, R. G.: Luminescence dating in archaeology:from origins to optical, Radiat. Meas., 27, 819-892, 1997.

Roberts, R. G., Jacobs, Z., Li, B., Jankowski, N. R., Cunningham, A. C., and Rosenfeld, A. B.: Optical dating in archaeology: thirty years in retrospect and grand challenges for the future, J. Archaeol. Sci., 56, 41-60, 2015.

Schmid, E.: Höhlenforschung und sedimentanalyse. Ein Beitrag zur Datierung des Alpinen Paläolithikums, Verlag des Institutes für Ur- und Frühgeschichte der Schweiz, Basel, 1958.

Stehlin, H.-G. and Dubois, A.: Notes préliminaires sur les fouilles entreprises dans la Grotte de Cotencher (canton de Neuchâtel), Eclogae Geol. Helv., 14, 240-242, 1916.

St Pierre, E., Zhao, J.-X., and Reed, E.: Expanding the utility of Uranium-series dating of speleothems for archaeological and palaeontological applications, J. Archaeol. Sci., 36, 1416-1423, 2009.

Taylor, R. and Bar-Yosef, O.: Radiocarbon Dating, Walnut Creek, California, Left Coast Press, Walnut Creek, California, 2014.

Thew, N., Hadorn, P., and Coope, G. R.: Hauterive/Rouges-Terres. Reconstruction of Upper Palaeolithic and Early Mesolithic natural environments, Office et musée cantonal d'archéologie, Neuchâtel, 2009.

Thomsen, K. J., Murray, A. S., Jain, M., and Bøtter-Jensen, L.: Laboratory fading rates of various luminescence signals from feldspar-rich sediment extracts, Radiat. Meas., 43, 1474-1486, 2008.

Tillet, T.: Le Moustérien dans l'arc alpin: complémentarité entre sites en grotte et sites en plein-air, in: Les Paléoalpins, hommage à Pierre Bintz, edited by: Tillet, T., Université de Grenoble, Grenoble, 99-106, 2000.

Tillet, T.: Le Paléolithique moyen dans les Alpes et le Jura: exploitation de milieux de contraintes d'altitude, in: Settlement dynam- 
ics of the middle Palaeolithic and Middle Stone Age, edited by: Conard, N. J., Kerns Verlag, Tübingen, 421-446, 2001.

Vouga, D.: Le Paléolitique, Mémoires de la Société Neuchâteloise des Sciences Naturelles, 7, 18-28, 1943.

Wallinga, J., Bos, A. J. J., Dorenbos, P., Murray, A. S., and Schokker, J.: A test case for anomalous fading correction in IRSL dating, Quaternary Geochronol., 2, 216-221, 2007.

Wegmüller, S., Preusser, F., and Müller, B. U.: Palynostratigraphische Untersuchung und Lumineszenzdatierung des Profils Galgenmoos und Implikationen für die Chronologie des letzten Glazialzyklus im nördlichen Alpenvorland der Schweiz, Eclogae Geol. Helv., 95, 115-126, 2002.

Welten, M.: Verdrängung und Vernichtung der anspruchsvollen Gehölze am Beginn der letzten Eiszeit und die Korrelation der Frühwürm- Interstadiale in Mittel- und Nordeuropa, Eiszeitalter und Gegenwart, 31, 187-202, 1991.
White, W. B.: Cave sediments and paleoclimate, J. Cave Karst Stud., 69, 76-93, 2007.

Wintle, A. G. and Murray, A. S.: A review of quartz optically stimulated luminescence characteristics and their relevance in singlealiquot regeneration dating protocols, Radiat. Meas., 41, 369391, 2006.

Zander, A., Degering, D., Preusser, F., Kasper, H. U., and Brückner, H.: Optically stimulated luminescence dating of sublittoral and intertidal sediments from Dubai, UAE: Radioactive disequilibria in the uranium decay series, Quaternary Geochronol., 2, 123 128, 2007. 